\title{
43. MAGNETIC ANOMALIES AND SEA-FLOOR SPREADING IN THE WESTERN NORTH ATLANTIC, AND A REVISED CALIBRATION OF THE KEATHLEY (M) GEOMAGNETIC REVERSAL CHRONOLOGY
}

\author{
P. R. Vogt, Naval Research Laboratory, Washington, D. C. \\ and
}

A. M. Einwich, Naval Oceanographic Research and Development Activity, Bay St. Louis, Mississippi

\section{INTRODUCTION}

The central North Atlantic is the oldest rifted ocean basin on earth. More or less continuous spreading through 180 to 190 million years has left many kinds of records in the crust and its sediment blanket. In this paper we reconsider, in light of DSDP drilling results, chiefly those of Leg 43 (Figure 1), the available magnetic data collected in the western North Atlantic. Since the drilling sites of Leg 43 lie on-and the lion's share of detailed magnetic data pertain to-Mesozoic crust, we discuss Cenozoic events only for comparative purposes. Emphasis is on recalibrating the Upper Jurassic to Lower Cretaceous Keathley series of geomagnetic reversals (Vogt et al., 1971a; Larson and Pitman, 1972; Larson and Hilde, 1975). Some of the magnetic data reported here are new, or were previously presented only at professional meetings (e.g., Vogt et al., 1970b; Einwich and Vogt, 1971; Einwich, 1972). Other magnetic data were published long ago (e.g., Walczak, 1963; Bracey, 1968; Taylor et al., 1968) but demand reconsideration in light of modern concepts such as plate tectonics and hot spots, and modern "ground truth" data provided by the Deep Sea Drilling Project. Many ingenious interpretations of high-quality data had to be revised or refuted but a few years later. In the final analysis it is the data that will survive longest, as illustrated by our inclusion here of data collected even before the plate tectonics revolution began.

\section{THE KEATHLEY (M) SEQUENCE: HISTORICAL BACKGROUND}

The first reversal chronology to be constructed from marine magnetic anomalies on the basis of the VineMatthews (1963) hypothesis went back to the Late Cretaceous, where it stopped for an apparent dearth of older correlatable lineations (Heirtzler et al., 1968). Although subsequent deep-sea drilling results and terrestrial data have prompted revisions of the 1968 reversal time scale, none of these revisions (e.g., Sclater et al., 1972; Tarling and Mitchell, 1976; La Brecque et al., 1977) differed from the Heirtzler scale by more than about $10 \mathrm{~m} . y$. This is remarkable, considering the control data available in 1968.

An extension of the reversal time scale into the Early Cretaceous and Late Jurassic was anticipated in several papers as old as, or even predating Heirtzler et al. (1968). In the Pacific, magnetic lineations now known to belong to the Keathley $(M)$ series were mapped east of Japan by Uyeda et al. (1962), about the same time as the Mason and Raff (1961) surveys west of California. Hayes and Pitman (1970) found another group of anomalies west of the Hawaiian ridge, and suggested that both lineation groups record one set of early or mid-Mesozoic reversals. The relation between the "Japanese" and "Hawaiian" lineations was further examined by Isezaki (1973), using data collected by USNS Silas Bent and F. V. Hunt, as well as other sources. A third set of Mesozoic anomalies ("Phoenix lineations") was then found and correlated with the other two, with the help of magnetized block models (Larson and Chase, 1972). A reversal chronology was derived from Pacific anomaly data, on the assumption that the Hawaiian lineations were formed at a constant spreading rate (Larson and Pitman, 1972).

In the Atlantic, the same Mesozoic $(M)$ lineation pattern clearly appears north of the Bahamas in the anomaly chart compilation of Bracey (1968), although he preferred to explain the features as younger, structural consequences of Caribbean-North Atlantic tectonics. This chart was based on sources dating back to Bracey and Avery (1963). Meanwhile, east-west profiles were being collected at a 20 -mile separation across the southwestern North Atlantic west of longitude $60^{\circ} \mathrm{W}$. These profiles (Figures 2 through 4 ) provided a clear and continuous record of the Mesozoic lineation pattern (Anderson et al., 1969), and allowed the construction of a fairly detailed reversal time scale for the first time (Vogt et al., 1971a). This sequence of reversals-and the series of linear magnetic anomalies recording these reversals in the central North Atlanticwere named after the survey platform USNS Keathley. Although Vogt et al. (1971a) correctly recognized these Atlantic lineations as the same ones found in the older, western Pacific by Hayes and Pitman (1970), a correct detailed correlation had to await the discovery, by Larson and Pitman (1972) and Larson and Chase (1972), that the Pacific lineations had formed near and south of the equator. Thus, positive anomalies in the western North Atlantic correlate with negative anomalies in the western North Pacific. The higher Pacific spreading rates had produced a more detailed reversal record and led to a more detailed reversal time scale (Larson and Pitman, 1972). The calibration of that time scale could now draw on both Atlantic and Pacific drilling.

The old end of the Keathley sequence-the magnetic smooth-rough boundary-had been fixed at about 150 


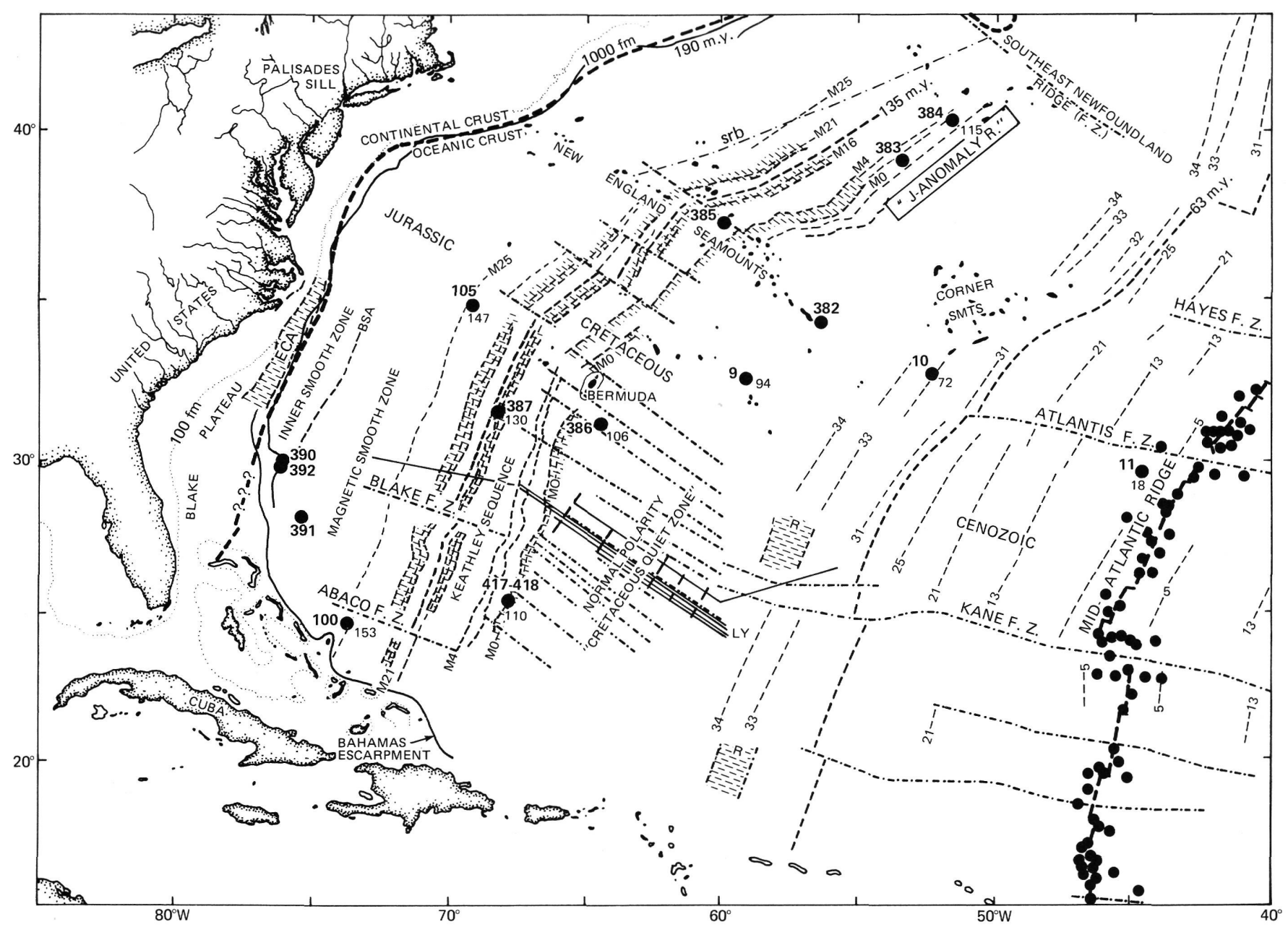

Figure 1. Magnetic lineations, DSDP sites and basement lineations in the western North Atlantic. Modified from Vogt et al. (1971b) by inclusion of DSDP sites, M-designation of Keathley sequence (Larson and Pitman, 1972), and Late CretaceousTertiary lineations (Cande and Kristoffersen, 1977). Heavy dashed lines show continent/ocean crustal boundary (Vogt, 1973), Jurassic/Cretaceous and Cretaceous/Tertiary boundaries, and present spreading axis. Lineations along J-anomaly ridge after Rabinowitz et al. (this volume); smooth-rough boundary (srb) and northeastern anomaly M-25 after Keen and Keen (1974) and Barrett and Keen (1976). Thin continuous lines show Lynch profile locations (Figure 10) across southern Bermuda Rise (Vogt and Johnson, 1971). Anomaly R (Vogt et al. 1971b) is the low between anomalies 33 and 34 (Cande and Kristoffersen, 1977). The 190-m.y. age for first sea-floor spreading is probably an upper limit.

to 155 m.y.B.P. by Atlantic drilling (Vogt et al., 1971a); the young end of this sequence was revised from 135 to about 110 m.y.B.P. by Larson and Pitman (1972). A further refinement of the Keathley $(M)$ reversal chronology was proposed by Larson and Hilde (1975) on the basis of additional magnetic and DSDP drilling data. The dating of the reversals has been based on the principle that the oldest sediment, directly overlying pillow basalt, equals the age of the underlying crust. Thus, revisions in the stratigraphic time scale-in this case the absolute ages of Upper Jurassic to Lower Cretaceous stage boundaries-obviously imply revisions in the magnetic reversal time scale. The reversal chronology offered in this paper as an update of Larson and Hilde (1975) is based not only on new drill-hole results (Leg 43), but also on a new stratigraphic time scale (van Hinte, 1976a, b).
Further magnetic investigations mapped the extent of the Keathley lineations in the North Atlantic, but have not contributed to refining the reversal time scale. This is mainly because of the relatively slow Atlantic spreading rate $(\sim 1$ to $2 \mathrm{~cm} /$ year $)$, which reduces the resolution. The Keathley lineations have now been mapped also from Bermuda northeast to the Grand Banks continental margin (Figure 1; Vogt et al., 1970; Schouten and Klitgord, 1977; Barrett and Keen, 1976; Rabinowitz et al., this volume). The most detailed picture of the western Atlantic Keathley anomalies emerged from an aeromagnetic survey southeast of Bermuda, and will be discussed later (Figure 5). The aeromagnetic data reported by Vogt et al. (1970a) are shown in Figures 6 through 9.

An eastern Atlantic mirror-image of the Keathley lineations was expected on the basis of relatively sym- 


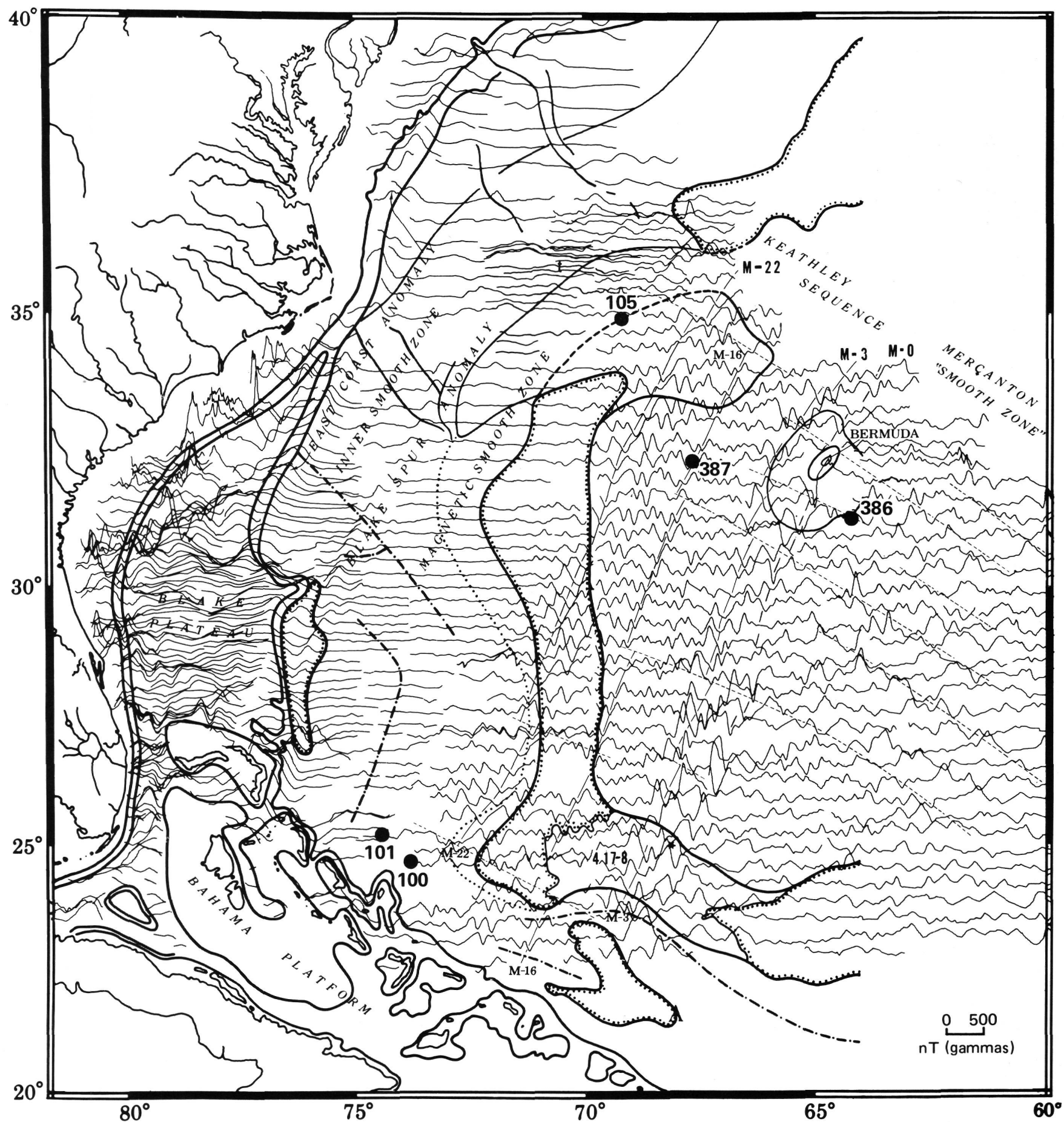

Figure 2. Magnetic anomalies in the southwestern North Atlantic (Vogt et al., 1971a; Einwich and Vogt, 1971; Einwich, 1972; Einwich, in preparation), physiographic province boundaries, and DSDP drilling sites. All profiles were collected by ship, most of them by USNS Keathley.

metric spreading. Although the data set there is nowhere so complete, eastern Keathley anomalies have been described (Vogt et al., 1970b; Laughton and Whitmarsh, 1974; Hayes and Rabinowitz, 1975; Jones and Mgbatogu, 1977). However, meaningful correlations of magnetic lineations in the North Atlantic are difficult or impossible with wide-spaced random tracks, and such data density is still the rule rather than the exception. Thus, some of the correlations suggested by Laughton and Whitmarsh (1974) and Jones and Mgbatogu (1977) are likely to be no less futile than those proposed by Emery et al. (1970; fig. 24) on the basis of several random tracks across the western Bermuda Rise. 


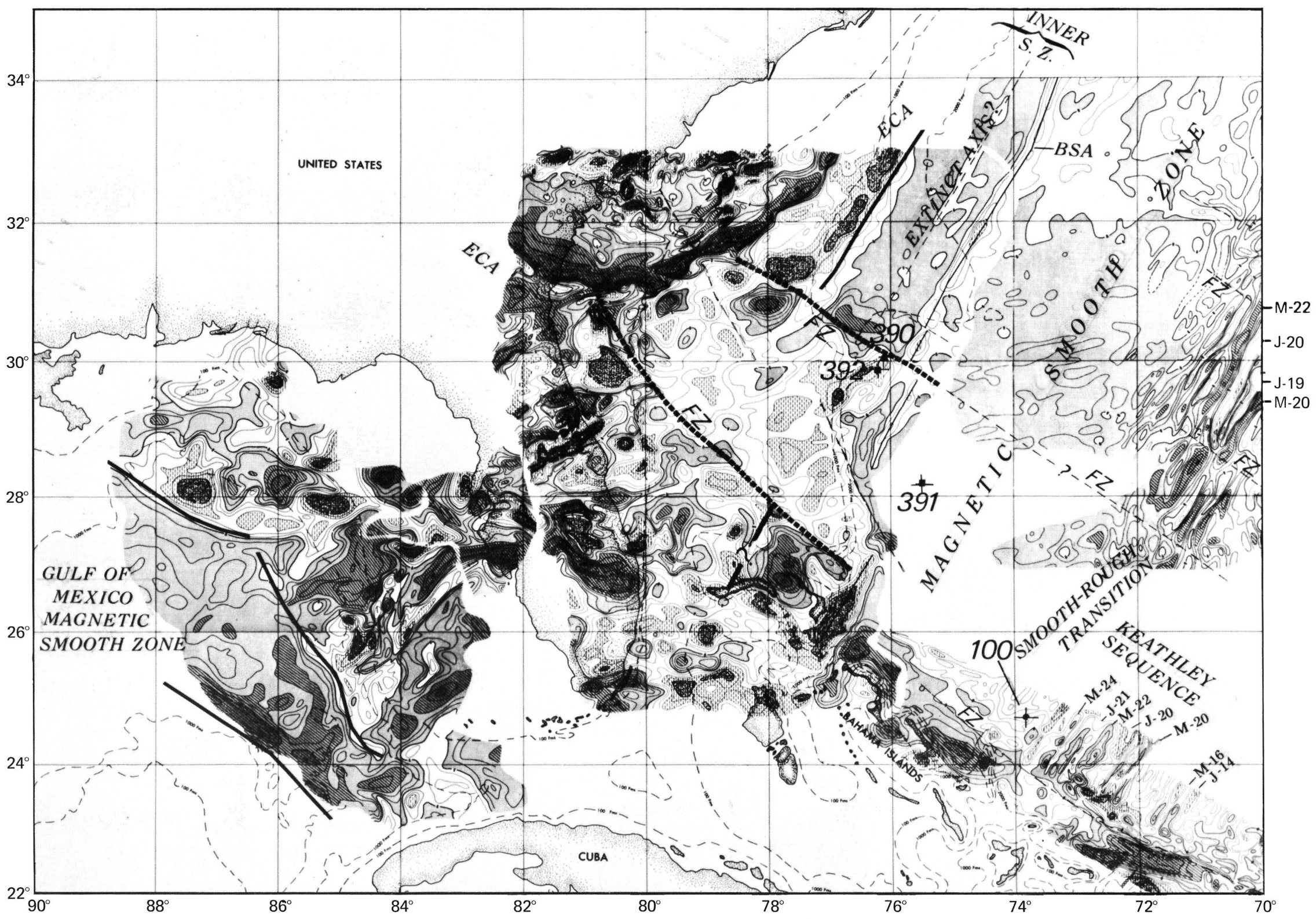

Figure 3. 250-nT residual magnetic contours in the area of the Blake Plateau and southern magnetic smooth zone. White strips separate different surveys. Constructed from data published by Bracey (1963), Vogt, et al. (1971a), Taylor et al. (1968), Martin and Case (1975), Meyerhoff and Hatton (1974), and previously unpublished data collected by the Magnetics Division of the U.S. Naval Oceanographic Office. Contours are unreliable in magnetic smooth zones. Heavy line shows proposed boundary between continental and oceanic crust (see Vogt, 1973). Boundary position is uncertain in area of central Blake Plateau. 


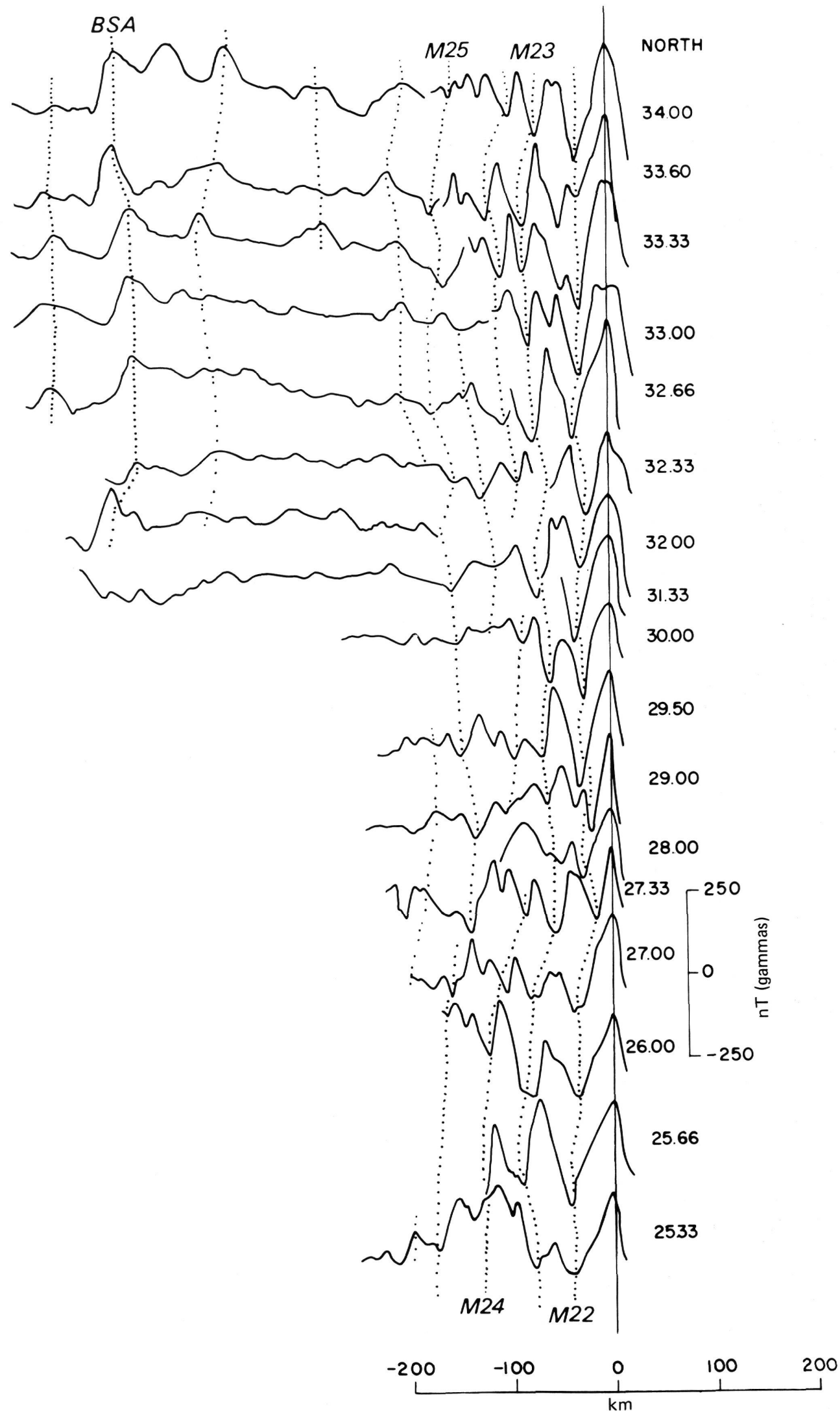

Figure 4. Residual east-west magnetic profiles across magnetic smooth zone and transition to oldest Keathley lineations. Profiles stacked on anomaly J-20. Reproduced from Vogt, et al. (1970b): anomaly identifications according to $\mathrm{M}$ convention of Larson and Pitman (1972) and Larson and Hilde (1975). 


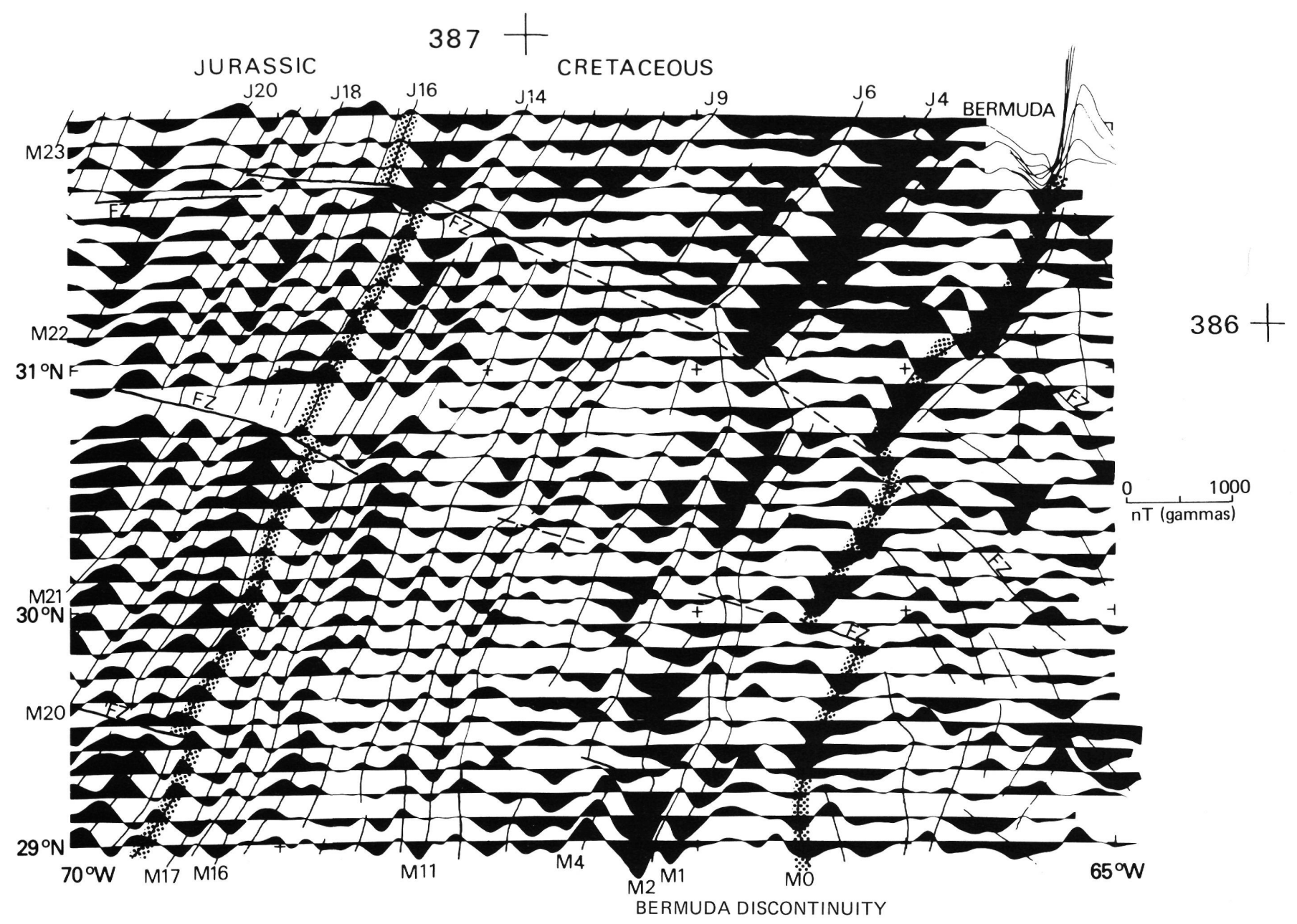

Figure 5. Detailed aeromagnetic survey of Keathley sequence, conducted by Project MAGNET over southwestern quadrant of Bermuda Rise. All residual profiles were adjusted by the same amount, so as to reduce the average anomaly over survey area to approximately zero. Anomaly identifications according to original $\mathrm{J}$ designations of Vogt et al. (1971a) at top, and corresponding M designations (Larson and Hilde, 1975) along left margin and bottom. Lines show magnetic lineation trends. Note confused but high-amplitude pattern over "Cretaceous quiet zone" southeast of Bermuda discontinuity, and lack of any "throughgoing" fracture zones. A detailed analysis of these data is in preparation.

There has been no final consensus on the nomenclature of the Mesozoic reversal sequence. Vogt et al. (1971a) assigned numbers, increasing with age, to prominent positive anomalies in the western North Atlantic. In the mistaken belief that all lineations were Jurassic, they assigned a prefix $J$ to distinguish the anomalies from those described by Heirtzler et al. (1968). All of the originally proposed $J$ lineations have subsequently been demonstrated to represent reversals, except for $J-1, J-2$ and $J-3$, which turned out to be local (topographic) features of the magnetic field. Later correlations with Pacific lineations, and the use of additional borehole ages, led to the $M$ (Mesozoic) nomenclature (Larson and Pitman, 1972). Those authors assigned numbers to positive anomalies, but since these generally (in the Pacific) resulted from reversed geomagnetic periods, the numbering is inconsistent with the precedent set by earlier workers (e.g., Heirtzler et al., 1968), and in the North and South Atlantic necessitates numbering of negative anomalies. Still more confusion was introduced with the numbering of two negative (Pacific) features as well (M-2 and $M-4)$. An anomaly younger than $M-1$ was subsequently found, and called $M-0$ (Larson and Hilde, 1975), or $C L$ (Hilde et al., 1976). We can only suggest that the Keathley anomalies be renumbered, consecutively after anomaly 34 , and that the numbers be restricted to normally magnetized blocks, in keeping with earlier usage (Heirtzler et al., 1968).

\section{MAGNETIC ANOMALIES IN THE WESTERN NORTH ATLANTIC}

Significant magnetic lineations, fracture zones, and relevant DSDP sites in the western North Atlantic are summarized in Figure 1. Basement ages at DSDP sites, as well as the position of the Jurassic/Cretaceous and Cretaceous/Tertiary boundary isochrons, are based on the reversal time scale in this paper and in La Brecque et al. (1977), and the stratigraphic time scale of van Hinte $(1976 a, b)$. Anomalies 34 and younger are from 


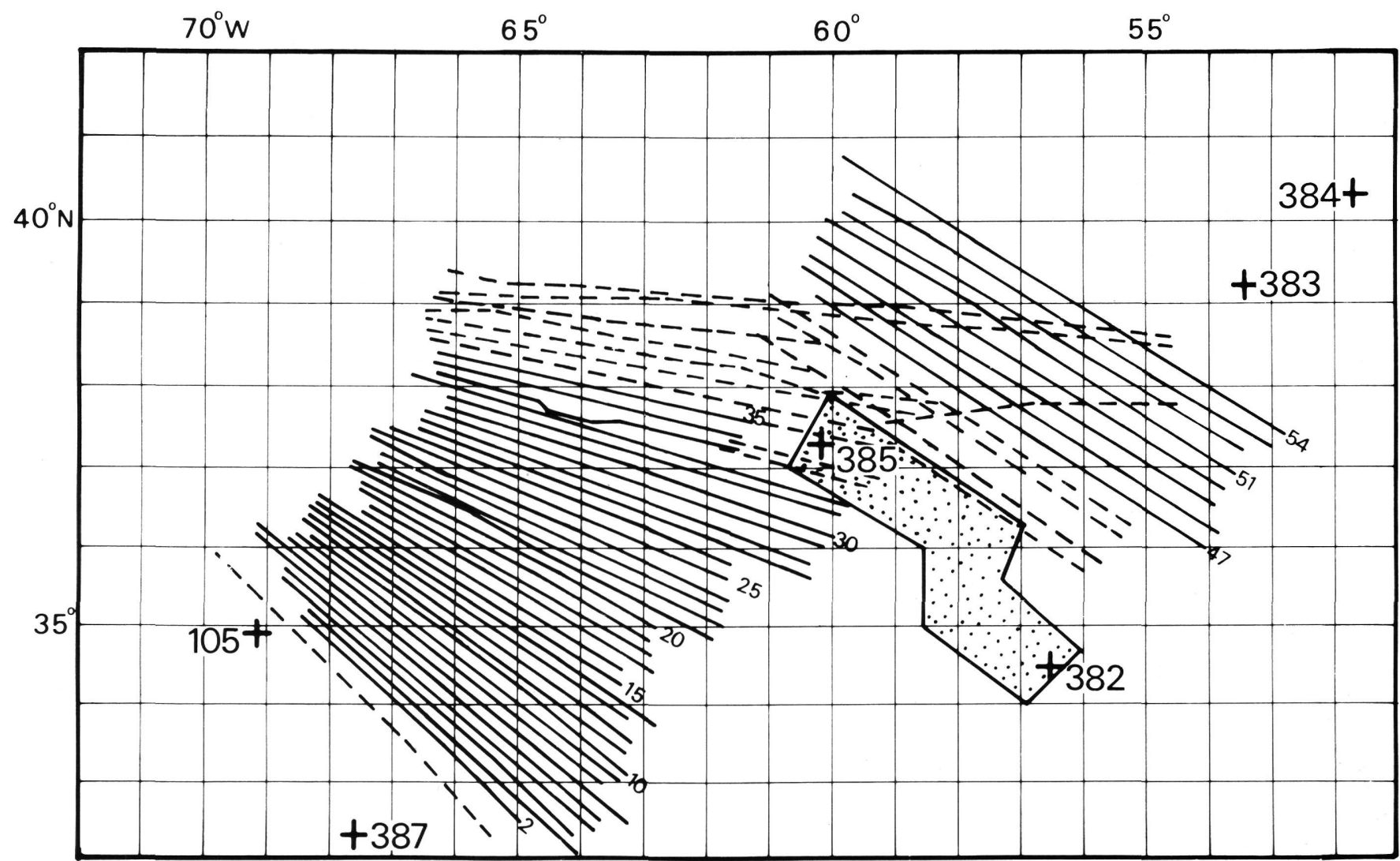

Figure 6. Index chart for aeromagnetic profiles collected by Project MAGNET between Bermuda Rise and southern Janomaly area (Vogt, et al., 1970a; Vogt, 1973). Crosses designate DSDP sites. Profiles for tracks shown by solid line are shown in Figures 7, 8, and 9. All flights were navigated by LORAN A, flight elevation was 330 meters, and total field measurements were made with a fluxgate magnetometer. Stippled area shows detailed shipborne survey published by Walczak (1963). See also Figure 1.

Cande and Kristoffersen (1977), who revised and extended the map of Pitman and Talwani (1972). Note that the broad negative anomaly called $R$ by Vogt et al. (1971a) is the low between anomalies 33 and 34 . The Keathley lineations are reproduced from Vogt et al. (1971a, b) with additions at the northeastern end from Rabinowitz et al. (this volume), Keen and Keen (1974), and Barrett and Keen (1976). The $J$ designations (Vogt et al., 1971a, b) have been replaced by the $M$ numbers proposed by Larson and Hilde (1975). The magnetic data on which the Keathley lineation pattern (Vogt et al., 1971a) is based (Figure 1) are shown in Figures 2 and 3 and 6 through 9. The compilation in Figure 2 also includes more recent data across the magnetic smooth zone and Blake Plateau (Einwich, 1972; Einwich and Vogt, 1971), and will be described in a separate publication. Results of the aeromagnetic survey which traced the Keathley lineations northeast of Bermuda (Vogt et al., 1970a) are reproduced in Figures 6 through 9. These data, not previously published, are not of the same high quality as the shipborne profiles (Figure 2) or a more recent detailed aeromagnetic survey (Figure 5). The earlier aeromagnetic work employed a fluxgate magnetometer whose precision for total field purposes is probably no bettern than \pm 15 $\mathrm{nT}$, and is not very satisfactory for describing anomalies with amplitudes less than 50 to $100 \mathrm{nT}$. Also, the navigation (LORAN-A) used on this survey is inferior to inertial and satellite methods currently in use (e.g., Figure 5). Nevertheless, the more prominent Keathley anomalies are easily identified on most profiles (Figures 6 through 9), and their location in Figure 1 is believed to be correct within $\pm 10 \mathrm{~km}$. (Greater errors could result from anomaly misidentification, of course.) The data reveal several fracture zones offsetting the linations pattern north of Bermuda (Figure 1); if there is an offset associated with the New England Seamount Chain, however, it must be minor (Figures 1 and 9). The observation that the lineations are essentially continuous through the area of the seamount chain (Vogt et al., 1970a) does rot support the concept, proposed by Drake et al. (1968), of a major fault-an extension of a Paleozoic fault interrupting Appalachian structures at $40^{\circ} \mathrm{N}$-continuing along the trend of the seamount chain. But the existence of a "Kelvin fault" is still endorsed by some authors (e.g., Rabinowitz, 1974), and may offer an alternative to the hot-spot hypothesis (see Vogt and Tucholke, this volume). Certainly the absence of a major anomaly offset (Figure 9) only rules out strike-slip faulting, not normal or thrust faults or flexures.

With one possible exception (anomaly $J-6$ or $M-4$ ), the Keathley lineations cannot be identified in the immediate environment of the New England (Kelvin) 


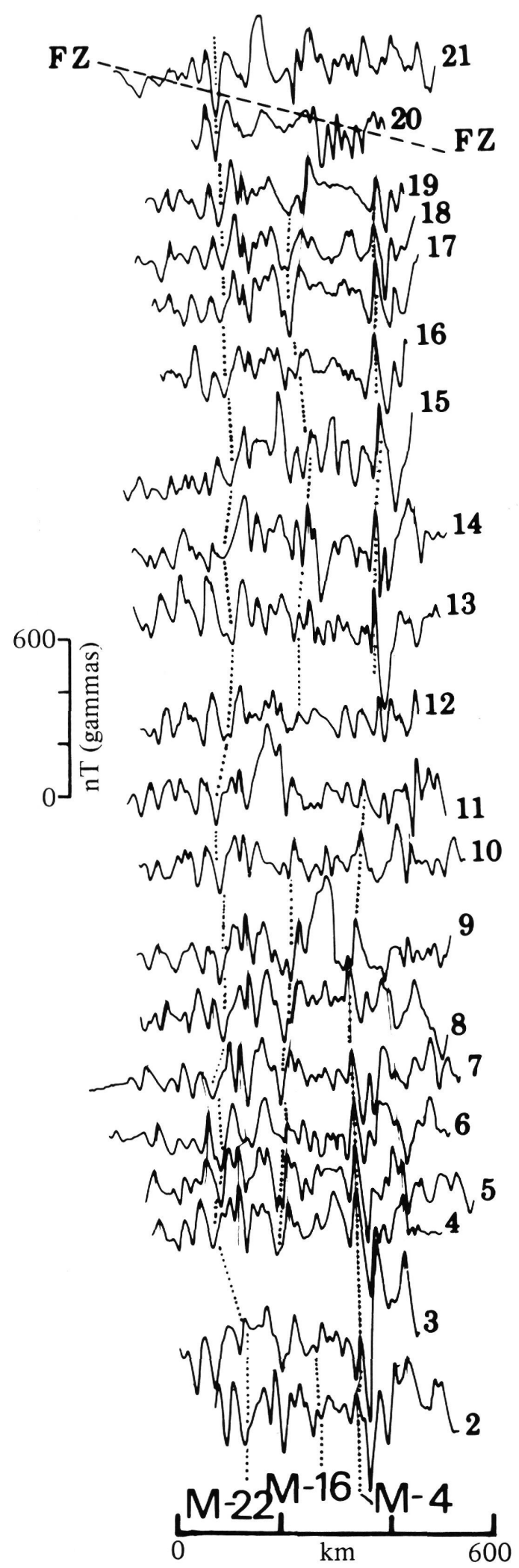

Figure 7. Profiles 2 to 21 (Figure 6) across the Keathley sequence on the northwest flank of Bermuda Rise. Dotted correlation lines show anomalies M-4, M-16, and M-22. Profiles are plotted at assumed constant aircraft speed and are stacked to facilitate anomaly correlation. Fracture zones implied by offsets are shown in Figure 1.

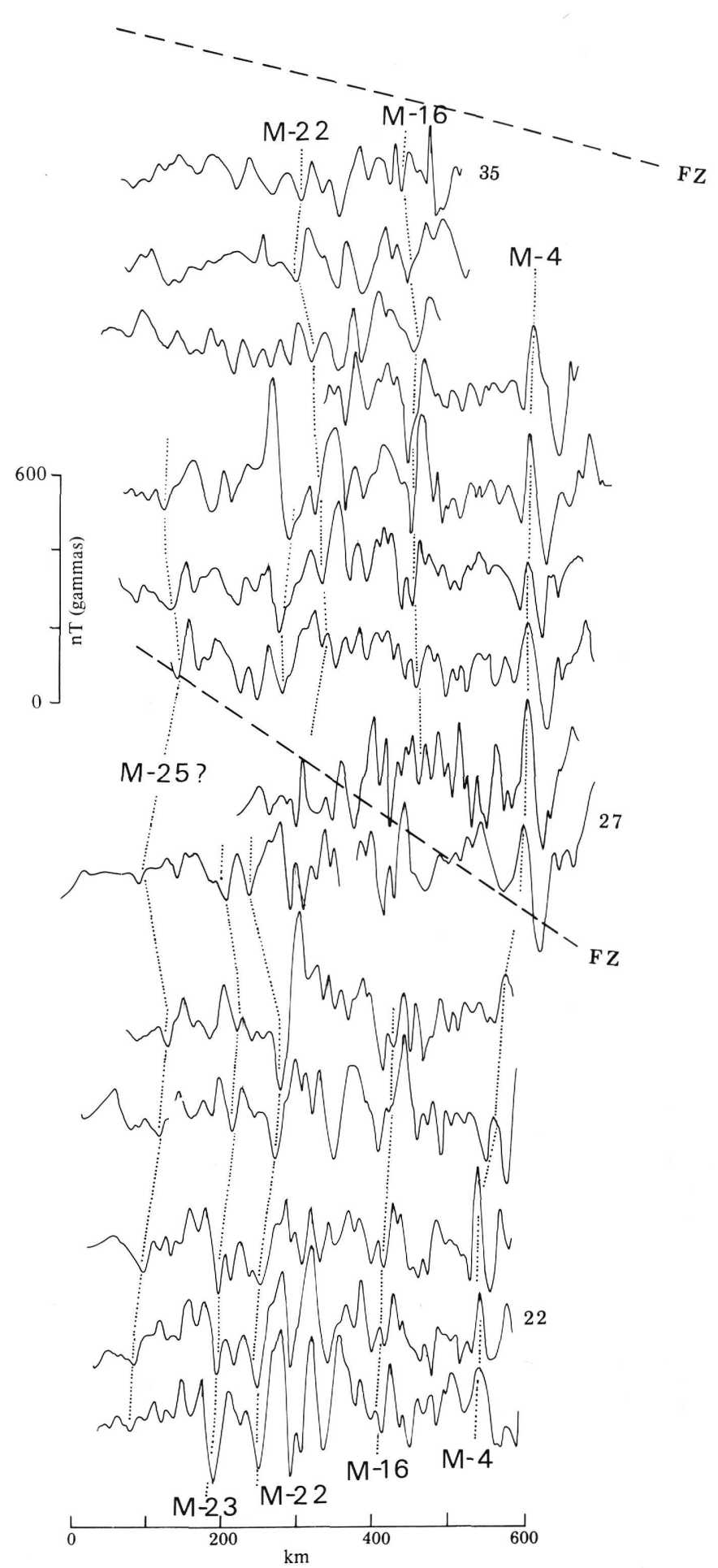

Figure 8. Profiles 22 to 35 across Keathley sequence south of New England Seamount Chain. Conventions as in Figure 7.

chain, because of the high-amplitude anomalies associated with the seamounts (Figure 9). The seamount anomalies have been mapped by Walzcak (1963) and Taylor et al. (1968). That most if not all of the seamount anomalies are positive, with slight negatives along their northern margins, is consistent with vol- 

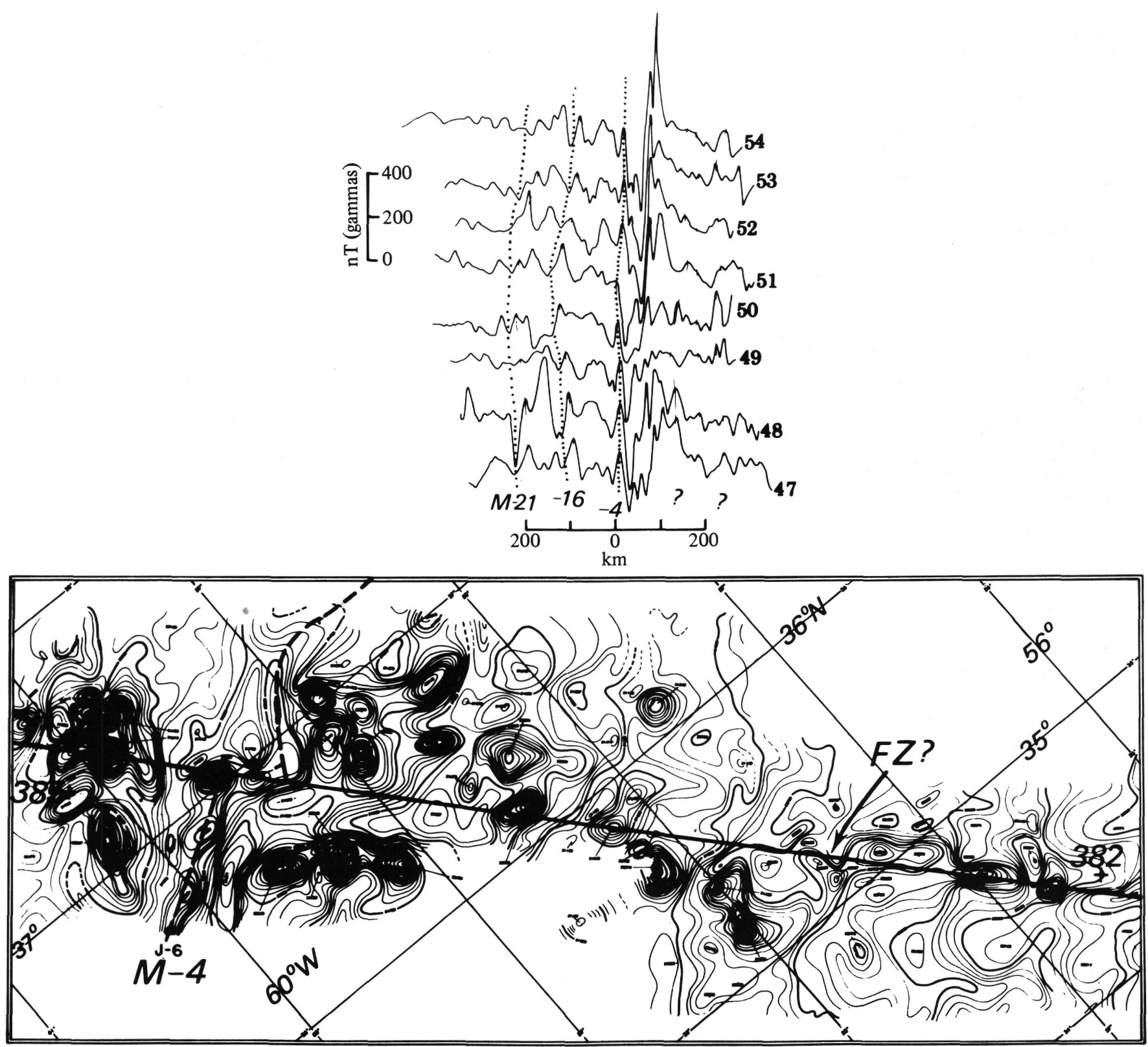

Figure 9. Profiles 47 to 54 across Keathley sequence (including high-amplitude J-anomaly) north of New England Seamount Chain. Conventions as in Figure 7. Bottom: Total intensity contour pattern (Walczak, 1963) in area of seamount chain, showing Leg 43 sites. Interpretation of even the prominent lineation M-4 (J-6) in seamount area is uncertain owing to high-amplitude anomalies caused by seamounts. A minor fracture zone ("FZ") offsetting this lineation may have helped localize later volcanism associated with "New England hot spot"(Vogt and Tucholke, this volume).

canic activity during a time of predominantly normal polarity, which lasted from about 110 or 115 to about 80 m.y. ago. Drilling results at Sites 382 and 385, in combination with other data, strongly suggest that most of the seamounts were formed during this period (see Figures 1 and 2 of Vogt and Tucholke, this volume).

Northeast of the New England Seamounts, the Keathley lineations bend to a less easterly trend, and probably continue as far as the Southeast Newfound- land Ridge and Grand Banks margin, which is interpreted as a major fracture zone (Figure 1). We suggest that the anomaly identifications of Barrett and Keen (1976) in this area are incorrect because they were based on insufficient data. Very high amplitudes associated with anomalies $M-0$ to $M-2$ northeast of $37^{\circ} \mathrm{N}$ demand an anomalously thick magnetized crust or a magnetization intensity several times normal (Rabinowitz et al., this volume). This " $J$-anomaly," first no- 
ticed by Heezen et al. (1959), is clearly evident in profiles 47 to 54 (Figure 9). The high crustal magnetization implied by the " $J$-anomaly" lies somewhat east of-but is evidently related to-a basement ridge and west-facing escarpment (Vogt et al., 1971b; Rabinowitz et al., this volume; Tucholke and Vogt, this volume). Both the basement features and the high-amplitude anomalies have counterparts in the eastern Atlantic, and evidently reflect events occurring at the axis of the mid-Cretaceous Mid-Atlantic Ridge.

The age and composition of Site 384 basement basalt, together with magnetic anomaly data and geometric considerations, lead us to reject the suggestion of Gradstein et al. (1977) and Grant (1977) that the $J$-anomaly ridge is a sliver of continental crust (see also Tucholke and Vogt, this volume).

Results of the most detailed magnetic study to date of the Keathley lineations are shown in Figure 5. This aeromagentic survey extends from the so-called Cretaceous "quiet zone" westward to anomaly $M-23$. A detailed analysis of these data is in preparation. We note here that almost all the numbered $M$-anomalies (but not, of course, all the reversals seen in Pacific data), can be identified, despite the comparatively slow spreading rate. Although anomalies $M-5$ to $M$-10 cannot be resolved as separate features, they coalesce locally to form recognizable lineations. Both anomalies $M-13$ and $M-14$ can be locally distinguished-just barely-and illustrate the resolution limit here. The close-spaced data (Figure 5) reveal minor bends and fracture zones not shown in Figures 1 and 2. These minor fracture zones and bends appear and disappear; it is doubtful that any transform fault extends entirely through the Keathley lineations in the area of Figure 5. Nor is there any evidence for the major Kane Fracture Zone (Figure 1), which should pass through the area, if that fracture zone existed at the time. The fracture zones observed there are minor and discontinuous (Figure 5). These observations also cast doubt on attempts to extrapolate fracture zones entirely through the magnetic smooth zone to the continental margin (Klitgord and Behrendt, 1976). Sometime after anomaly $M-11$ time, the spreading axis configuration began to become more complex. Even greater changes, combined with along-strike amplitude variations, occurred after anomaly $M-4$. Note the highly variable separation between anomalies $M-0$ and $M-4$, compared for example with the separation between $M-15$ and $M-20$ (Figure 5). There is also evidence that at about anomaly $M-4$ to $M-0$ time a change occurred in plate rotation pole, since fracture zones take on a more southerly trend. The $J$-anomaly and its basement ridges (Figures 1 and 9) also lie in the $M-0$ to $M-4$ zone, called the "Bermuda discontinuity" (Vogt et al., 1971b) because Bermuda lies along this belt. (The Bermuda volcanoes, however, are primarily Eocene to Oligocene, much younger than the crust on which they stand [Tucholke and Vogt, this volume]). East of anomaly $M-0$ and the Bermuda discontinuity lies crust believed to have been formed during a period of relatively few reversals (Helsley and Steiner, 1969; McElhinney and Burek,
1971; Larson and Hilde, 1975; Hilde et al., 1976). Yet, relatively high-amplitude magnetic anomalies occur there (Figures 2 and 5); it is incorrect to speak of a Cretaceous "quiet zone" in the North Atlantic. The anomaly pattern is quite irregular, although the dominant trends (Figure 2) reflect fracture zones (Vogt et al., 1971a), and may be caused by the contrast between normally magnetized crust and relatively nonmagnetized fracture zone crust. However, even profiles taken between and paralleling fracture zones (Figures 1 and 10; Vogt and Johnson, 1971) reveal anomalies almost as high in amplitude as those of the Keathley series. Note the difference between the Cretaceous "quiet zone" and the Jurassic quiet (or smooth) zone west of the Keathley anomalies (Figure 10). If the post-Keathley anomalies are caused by magnetization contrast within a $\sim 300$ - to 600-meter- thick layer, a relatively high magnetization contrast of $1.5 \times 10^{-2}$ emu $\mathrm{cm}^{-3}$ is required, as indicated by the block model in Figure 10. (This block model is shown for comparative purposes only; it is not meant to imply a mid-Cretaceous reversal sequence.) Furthermore, it is likely that most of the magnetization remaining in crust of this age ( $\sim 80$ to 110 m.y.) resides in the $\sim 2-\mathrm{km}$-thick dike layer below the pillow basalts (Blakely, 1976).

Some of the blocks in Figure 10 may represent actual reversed periods within the long Cretaceous normal (or Mercanton) interval (Vogt and Johnson, 1971). This would of course halve the required magnetization intensity for some blocks. There is evidence from sediments (Keating and Helsely, this volume) and from Pacific magnetic profiles (Hilde et al., 1976) that at least a few short reversed periods occurred between anomalies $M-0$ and 34 ; but most of the anomalies in the Cretaceous "quiet zone" (Figure 10) were probably not caused by reversals. Alternative explanations include basement topography, intra-basement magnetization contrast, and perhaps long-period geomagnetic intensity fluctuations (Vogt and Johnson, 1971). (In the latter case one should expect correlatable anomalies in other oceans, and this has not been demonstrated). Only the North Atlantic north of about $20^{\circ} \mathrm{N}$ shows a "noisy" magnetic signature over crust about 110 to 80 m.y. old (Vogt et al., 1971a, b; Laughton and Whitmarsh, 1974; Hayes and Rabinowitz, 1975; Barrett and Keen, 1976). Furthermore, unpublished calculations based on the Lynch profiles (Figures 1 and 10) show only a mediocre correlation between the anomalies and basement topography, and in any case relatively high values of magnetization are unavoidable, 10 times higher than suggested by Blakely (1976) for crust of such age. Since the basement relief is of the same magnitude as the supposed thickness of pillow basalts $(\sim 500 \mathrm{~m})$, Blakely's model suggests that the basement topography should no longer retain a strong magnetization; the poor correlation between magnetic anomalies and basement topography is therefore perhaps not surprising. This leaves intra-basement magnetization contrast, probably largely within the dike layer, as the major cause. Such contrast could not exist within the Jurassic quiet zone, 


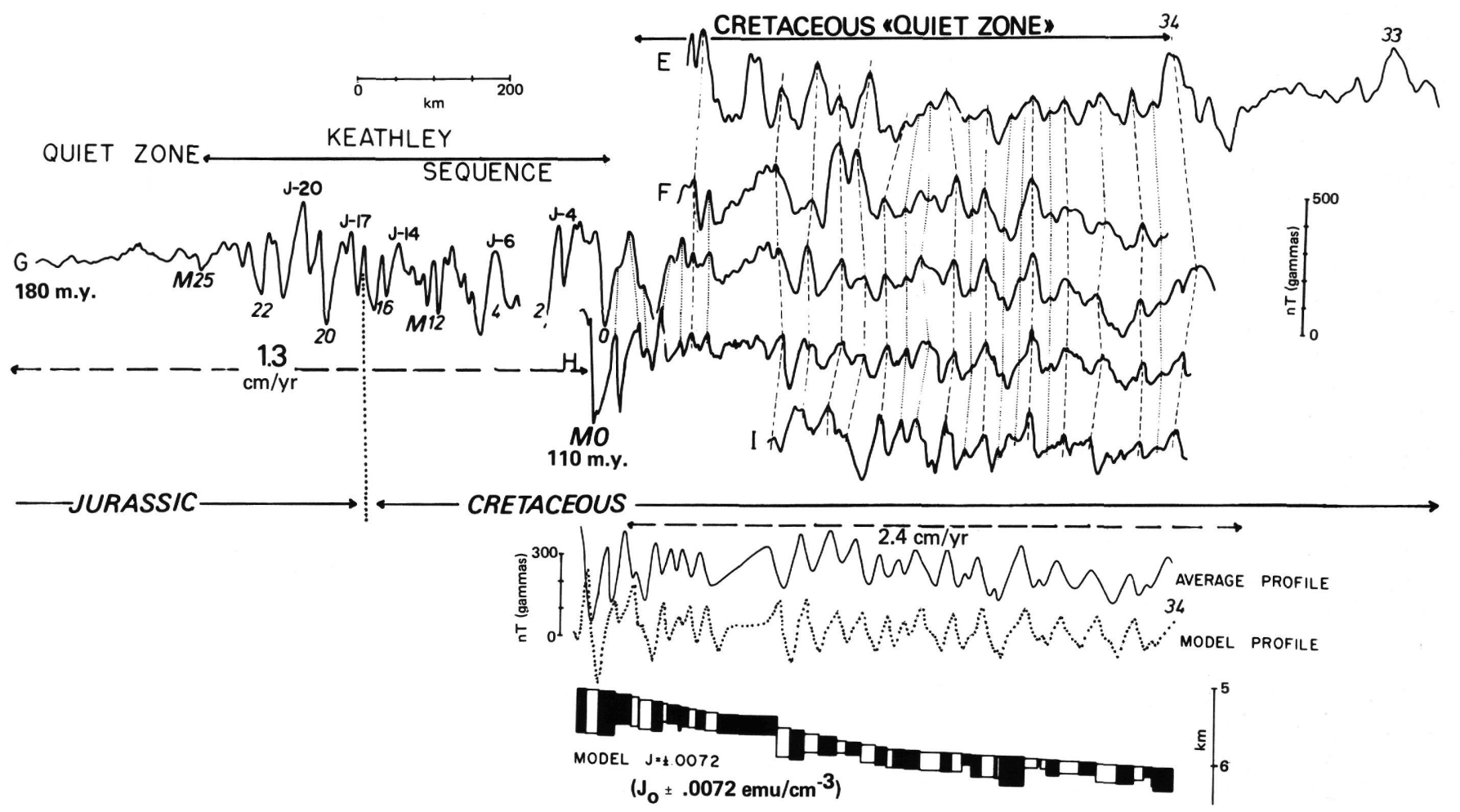

Figure 10. Shipborne magnetic profiles (USNS Lynch) across Keathley sequence (left) and Cretaceous "quiet zone" as far as anomalies 33 and 34 (right). Profiles (labeled LY on Figure 1) parallel fracture zones in Cretaceous "quiet zone" on east flank of Bermuda Rise. Model fit to average profile (bottom) shows magnitude of magnetization contrast required

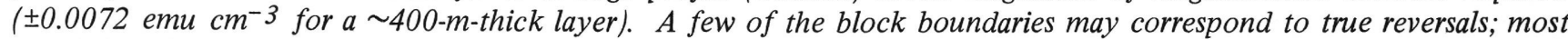
probably reflect basement topography, intra-basement structure, or possibly paleomagnetic intensity fluctuation. Modified from Vogt and Johnson (1971).

else it would not be so quiet, or within much of the Keathley lineations, else these would not be so regular (e.g., Figure 5). So we suspect that the geological processes operating at the Mid-Atlantic accretion axis must have changed from the time of the Jurassic smooth zone and Keathley sequence to the time of the mid-Cretaceous "quiet zone." In addition, a relatively stronger mid-Cretaceous dipole field may have existed, amplifying the magnetization contrasts caused by ridge-axis tectonic and igneous processes. The changes from Keathley ( $M$-Sequence) to Mercanton time probably did not begin abruptly at $M-0$ time; rather, the irregular amplitudes of lineations as old as $M-4$ (compared with $M-11$ to $M-22$, for example), suggest that the changes began before the end of Keathley time (Figure 5).

Why the Mid-Atlantic Ridge changed its spreading processes near the end of Keathley $(M)$ time remains open to speculation. Several observations are pertinent to this problem, however: (1) Since spreading rates changed from Keathley to Mercanton time $(\sim 110$ m.y.; Figure 11), the magnetization changes may relate to spreading rate changes. (2) The end of Keathley time may have corresponded to the beginning of spreading between equatorial Africa and South America, and between the Grand Banks and the Iberian Peninsula. This, together with changes in spreading rates and spreading directions between North American and
Africa (Figures 1 and 11), suggests that the Keathley interval ended at a time of major plate reorganization in the Atlantic (Vogt et al., 1971b). (3) The increase in spreading rate $(1.2$ to $2.4 \mathrm{~cm} /$ year; Figure 11) was dramatic, if not as great as first suspected (Hays and Pitman, 1973). The "coincidence" between the change in reversal frequency and major plate reorganization (or, at least, dramatic morphologic changes at the MAR crest, e.g., the $J$-anomaly ridge) strongly indicates some type of coupling between processes operating in the earth's core and the dynamics of the crust and upper mantle (Vogt, 1975).

We conclude our discussion of magnetic anomalies in the western North Atlantic with a brief review of the magnetic smooth zone that lies between the Keathley lineations and the continental margin (Figures 1 through 4). At least south of $35^{\circ} \mathrm{N}$, the zone may be subdivided into a main or outer smooth zone about $370 \mathrm{~km}$ wide, and an inner smooth zone $120 \mathrm{~km}$ wide (Einwich and Vogt, 1971; Einwich, 1972; Vogt, 1973). The "East Coast anomaly" forms the landward margin of the inner smooth zone, and the two zones are separated by the Blake Spur anomaly. Since only the equivalent of the outer smooth zone exists along the margin of North Africa, Vogt (1973) suggested that an early spreading axis, long extinct, formed the inner smooth zone. An eastward jump of the axis might have isolated a sliver of continental or transitional crust respon- 


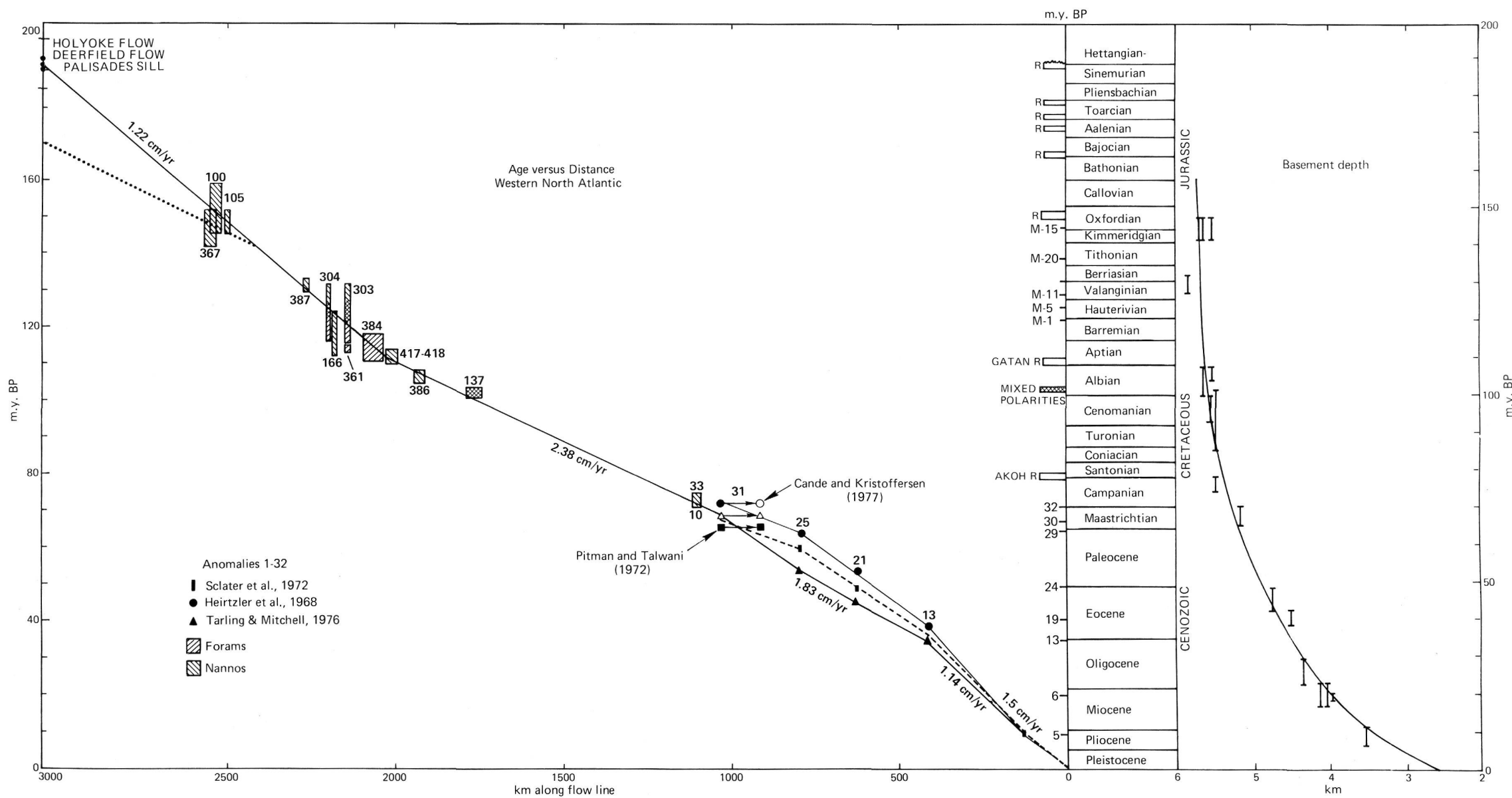

Figure 11. Age versus distance in the western North Atlantic, along flow line (Pitman and Talwani, 1972) passing through Site 386. Other DSDP-determined basement ages are interpolated to locations along this flow line. Three proposed reversal chronologies are shown for Cenozoic reversal sequence (Heirtzler et al., 1968; Sclater et al., 1972; Tarling and Mitchell, 1976). Radiometric ages of Holyoke and Deerfield flows and the Palisades Sill (Dallmeyer, 1975) are plotted where the flow line intercepts the continental margin, because they probably erupted about the time of initial rifting, or earlier (Scrutton, 1973; Tarling and Mitchell, 1976). Thus, 190 m.y. is probably an upper limit. Dotted line would not violate existing data. Stratigraphic and magnetic time scales are from van Hinte $(1967 a, b)$, and the basement subsidence curve (right), based on DSDP-determined basement ages, is from Tucholke and Vogt (this volume). Note that DSDP borehole data do not require a spreading-rate change in this area during Keathley time. 
sible for the relatively high-amplitude Blake Spur anomaly (Figures 3 and 4). Rabinowitz (1974) proposed that, alternatively, several polarity reversals were responsible for the Blake Spur anomaly. He also divides the magnetic smooth zone in the western North Atlantic into two subzones, but his boundary, an anomaly $E$, does not everywhere coincide with the Blake Spur anomaly used by Einwich (1972) to define the boundary between inner and outer smooth zones (Figures 1 through 4). Rabinowitz (1974) proposed that anomaly $E$ is the continent-ocean crustal boundary. Vogt (1973) suggested that the eastern or outer margin of the source body responsible for the East Coast anomaly is the continent-ocean crustal boundary (Figure 1). This is also approximately the location of the boundary implied by hypotheses explaining the anomaly as an "edge effect" (Keen and Keen, 1974). Other authors have explained the East Coast anomaly itself as an oceanic spreading-type lineation, and as a consequence have placed the ocean-continent crustal interface landward of the anomaly (Emery et al., 1970; Luyendyk and Bunce, 1973; Mayhew, 1974; Sheridan, 1974).

Although the exact continental-oceanic crustal boundary remains a matter of discussion (Mayhew, 1974; Rabinowitz, 1974; Keen and Keen, 1974; Sheridan, 1974), it is worth noting that a recently published multichannel reflection profile (Grow and Markl, 1977) shows oceanic basement extending landward almost to the landward edge of the inner smooth zone, in contradiction to the views of Rabinowitz (1974). Continental basement extends seaward almost to the landward edge of the East Coast anomaly, whereas the nature of the crust associated with the anomaly itself remains unknown (Grow and Markl, 1977). Thus, the multi-channel seismic data are consistent with a crustal boundary either at the seaward (Vogt, 1973) or landward margin (Sheridan, 1974; Mayhew, 1974) of the East Coast anomaly, or of course somewhere between.

In the area of the Blake Plateau, the inner smooth zone is replaced by complex, sublinear magnetic anomalies of relatively long wavelength (Figures 2 and 3; Einwich, 1972; Einwich and Vogt, in preparation). The location of the continent ocean crustal boundary is even more doubtful in this region (Figures 1 and 3). If the crust under much of the Blake Plateau was formed by a hot spot such as Iceland, both the shallow initial depth implied by carbonates and evaporites (Sheridan, 1974) and the character of the magnetic signature might be explained. (See also Newell, 1955, and Dietz et al., 1970.) The Blake Spur anomaly might then be an earlier analog of the $J$-anomaly (Figures 1 and 9; Rabinowitz et al., this volume), rather than the expression of a sliver of the East Coast anomaly source (Vogt, 1973, and fig. 10 of Sheridan, 1974). It is possible that a short section of inner smooth zone reappears as a relative negative anomaly just northeast of the western Bahamas (Figure 3). Accordingly, we have speculatively placed the continent-ocean crustal boundary immediately to the northwest of this feature (Figure 3). West of Blake Plateau lies the Florida platform, a large area of relatively high-amplitude anomlies, either irregular or trending northeast (Figure 3). With other authors (e.g., Sheridan, 1974), we interpret this province as continental basement. The magnetic anomalies continue westward well into the abyssal Gulf of Mexico, where they are replaced by a magnetic smooth zone (Figure 3; see also fig. 8 of Martin and Case, 1975). We have speculatively placed continent-ocean crustal boundaries in the eastern Gulf of Mexico and suggest that the smooth zone there may have an age and origin similar to that of the smooth zones east of the Florida platform and Blake Plateau.

Although numerous plausible mechanisms have been proposed to explain the magnetic smooth zones in the central North Atlantic (see review by Rabinowitz, 1974), the existence of coeval zones in the western $\mathrm{Pa}$ cific strongly suggests that some geomagnetic change was responsible (Larson and Pitman, 1972; Larson and Hilde, 1975). A gradual decrease in reversal frequency could explain the envelope of increasing amplitudes forming the younger margin of these smooth zones (Figures 2, 3, and 4). Any coupling of core and lithosphere behavior (Vogt, 1975) could, however, result in more or less simultaneous geomagnetic changes (e.g., reversal frequency) and geologic changes, such as changes in plate kinematics and accretion-zone dynamics. It is not certain, then, that the difference between the magnetic smooth zone and the Keathley anomalies (Figures 2 and 10) is entirely a function of reversal frequency and dipole intensity. Some of the difference could reflect polar wandering (Vogt et al., 1970b), insofar as recent paleomagnetic evidence is consistent with relatively rapid northward motion of the North American virtual pole (Steiner, 1975) during the time of the magnetic smooth-rough boundary (or transition; $\sim 140$ to 155 m.y. ago). Also, the role of sedimentation in suppressing magnetic amplitudes (Vogt et al., 1970b) may be important north of the New England Seamounts, where the smooth-rough boundary mapped by Keen and Keen (1974) appears to be timetransgressive with respect to Keathley lineation trends there (Figure 1). The oldest Keathley anomalies in that area may have "lost" their amplitudes as a result of sediment burial, either at the ancient spreading center or subsequently.

Although many authors now explain the smooth zone as the result of constant normal polarity during Middle to Early-Late Jurassic time (e.g., Larson and Hilde, 1975) there are relatively few land magnetic control data. There is evidence for at least a few reversed periods in the outer smooth zone (Barrett and Keen, 1976) and near the Blake Spur anomaly (Rabinowitz, 1974). Deep-tow profiles and basement samples have also been analyzed (Taylor et al., 1973; Taylor and Greenewalt, 1974), but the significance of the results for the smooth zone problem remains unclear, considering the geographic limitations of the observations and their location along the outer boundary rather than within the zone.

Since no DSDP hole has penetrated to basement in the smooth zone itself (Sites 100 and 105 lie in the 
transition zone; Figure 1), crustal ages have to be inferred by extrapolation. The dubious success and large variability of earlier extrapolations should serve as a warning: not long ago, the smooth zone was thought by some authors to be Paleozoic (Drake et al., 1968). From the basement dates available then (Sites 9, 10, and 11), Emery et al. (1970) extrapolated a Permian date (220 to 270 m.y. ago) for the zone (as also predicted by Heirtzler and Hayes, 1967). Vogt et al. (1970b) argued that the smooth-rough transition zone was formed around 190 m.y. ago; this estimate was still some 40 m.y. older than the actual age determined by drilling at Sites 100 and 105 . The age of the smooth zone was generally overestimated because (a) until the papers of Larson and Pitman (1972) and Hays and Pitman (1973), the Cretaceous episode of fast spreading (Figure 11) was unsuspected; and (b) the dearth of rock magnetic results from the Jurassic resulted in a preference for picking the Kiaman (Permian) interval as an explanation for the smooth zone.

Leg 43 drilling did not directly contribute to solving the smooth-zone problem, but the age-distance compilation (Figure 11) includes three basement ages from Leg 43, and offers the data from which any extrapolations must be made. It is interesting, although perhaps coincidental, that a straight line with a slope of 1.22 $\mathrm{cm} /$ year (spreading half-rate) adequately fits all basement ages $M-0$ and older, and intersects the continental margin (as defined in Figure 1) at around 190 m.y.B.P. If the better-known Greenland-Norwegian Sea can be used as a model (Tarling and Mitchell, 1976), then igneous activity exemplified by the Palisades Sill should have occurred at, or a few m.y. earlier than, the time of first spreading. We note that the 1.22 $\mathrm{cm} /$ year line intercepts the continental margin at the age of the Palisades Sill and related volcanics (Dallmeyer, 1975), which in Figure 11 are plotted at the position of the continental margin (Figure 1). We consider 190 m.y. ago as an early limit for the initiation of spreading. An age of 170 to 180 m.y. would not be unreasonable, but would require relatively faster spreading during the time of the smooth zone, and perhaps also the oldest Keathley lineations, as suggested by Larson and Pitman (1972). The complication introduced by an early jump of the spreading axis (Vogt, 1973) has not been considered in constructing Figure 11. In summary, our best estimate at this time is that the smooth zone was formed starting between 170 and 190 m.y. ago, and ending gradually 145 to 155 m.y. ago.

\section{IMPLICATIONS OF LEG 43 RESULTS FOR THE HISTORY OF SPREADING IN THE NORTH ATLANTIC, AND FOR THE KEATHLEY REVERSAL CHRONOLOGY}

\section{Evidence From Leg 43 Drilling}

On Leg 43, original oceanic basement ages were obtained at Sites 384, 386, and 387 in the western North Atlantic (Figures 1 and 12). "Paleontological" basement ages could be determined within an error bar

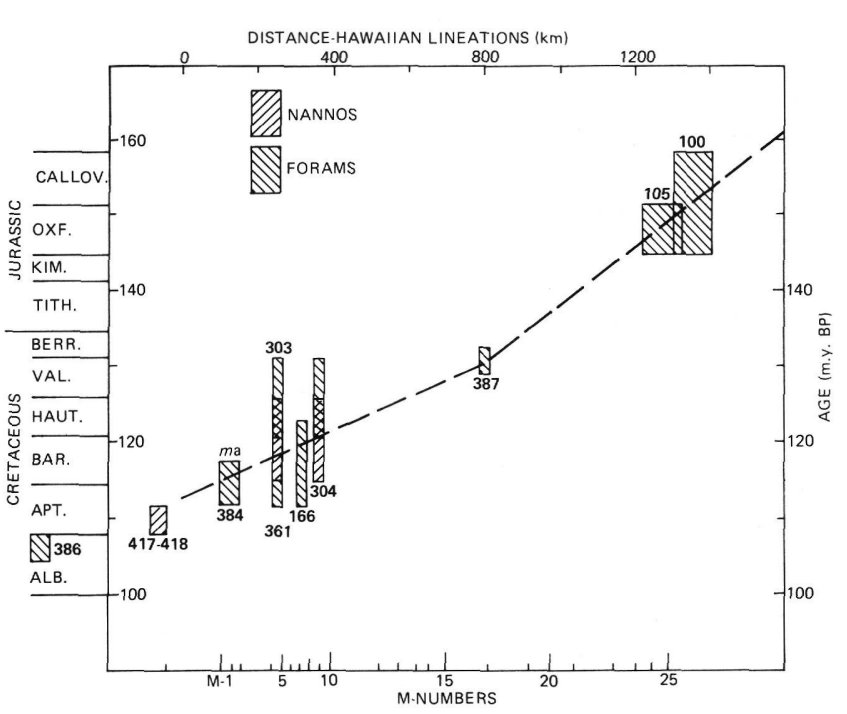

Figure 12. Basement ages for the Keathley sequence (Mseries) plotted against distance along Hawaiian lineations. Dashed line was used to build reversal chronology (Figure 13). Modified from Larson and Hilde (1975) by use of the van Hinte $(1967 a, b)$ time scale and inclusion of additional DSDP basement ages. Note that Site $387 \mathrm{sug}$ gests spreading rate was not constant for Hawaiian lineations, as proposed by Larson and Pitman (1972) and Larson and Hilde (1975). Macrofossils help constrain basement age only at Site 384 (ma). Site 386 basement age is plotted at a fictitious location east of $\mathrm{M}-0$ in the Hawaiian lineations, assuming spreading rates there did not change at $\mathrm{M}-0$ time.

about one Cretaceous stage in length. Considerably less reliable radiometric dating of the altered basement basalts ( \pm 10 to 20 m.y.) in general supports the absolute ages inferred from paleontology (Houghton et al., this volume). The significance of these basement ages and sediment magnetization studies (Opdyke, this volume, and Keating and Helsley, this volume) for the magnetic reversal chronology and sea-floor spreading in the central Atlantic is addressed in this section. The location of the sites within (384 and 387) and just on the young side (386) of the Keathley sequence ( $M$-series) of magnetic anomalies (Vogt et al., 1971a; Larson and Hilde, 1975) places additional constraints on the ages of the reversal sequence from paleontological and absolute dating. In addition, sediment magnetization studies (Keating and Helsely, this volume) at Site 386 suggest three brief reversed intervals in the Cenomanian and Albian, i.e., within the Cretaceous normal or Mercanton interval.

Let us consider the evidence from each drill site in turn, from old to young. Site 387 was placed in the middle of the Keathley sequence, between anomalies $M-15$ and $M-16$. One reason for selecting this site was to fill the gap in the age control between $M-10$ and $M-22$ (Larson and Hilde, 1975). A basement date of early Valanginian could be reliably determined from nannofossils (Okada and Thierstein, this volume) and roughly substantiated by a radiometric date of $126 \pm 20$ m.y. 
(Hougton et al., this volume). Although the igneous unit sampled is a sill, it is probably close in age to the entire crust below it (Houghton et al., this volume). Whether the Leg 17 time scale or the van Hinte $(1976 a, b)$ time scale is used for the Jurassic-Cretaceous, the basement at Site 387 is about 5 million years younger than predicted by the Larson-Hilde chronology; this is not a large discrepancy, but it does cast doubt on the assumption of Larson and Hilde that the Hawaiian lineations were formed at a constant spreading rate. If a curved or bent line is drawn through the existing data to accommodate the Site 387 basement age (Figure 12), it would mean that the early Hawaiian lineations (pre- $M-16$ ) were formed at a slower spreading rate than later lineations. We shall return to this point later.

Site 384 was placed on the crest of the spectacular $J$-anomaly ridge (see Site 384 Summary, this volume). Although the " $J$-anomaly" is no doubt complicated by the existence of highly magnetized rock or a thickened magnetic layer (Rabinowitz et al., this volume), we believe this "geologic noise" does not prevent identification of anomalies $M-2$ and $M-3$ west of the ridge. We consider the crest of the ridge, and so Site 384 , to be on anomaly $M-2$. There is some suggestion that the $J$-anomaly ridge and its eastern Atlantic counterpart are slightly time transgressive: of $M-2$ age in the northeast and $M-0$ age in the southwest (Tucholke and Vogt, this volume).

Three sorts of basement ages were obtained at Site 384. The bioclastic (rudist) reef debris is Aptian/Albian (see Site 384 report), and orbitoline foraminifers associated with the reef formation are probably upper Barremian. A whole-rock radiometric age of $104 \pm 6$ m.y.-a minimum value for the altered basalt underlying the reef-agrees substantially with the fossil ages, considering the uncertainties in radiometric dating (Houghton et al., this volume). We believe that the basement most probably dates from the late Barremian. If the $J$-anomaly ridge is that old, it and the associated anomaly must have been generated at or very near the axis of the ancient Mid-Atlantic Ridge, and do not represent some sort of later "geologic overprinting." Indeed, a mid-oceanic origin is independently suggested by the existence of a "mirror image" $J$-anomaly ridge in the eastern Atlantic, and by the tholeiitic composition of basalts below the reef (Houghton, this volume).

A late Barremian date for anomaly $M-2$ is in good agreement with the Larson-Hilde (1975) calibration line, and indicates that the "Bermuda discontinuity" (Vogt et al., 1971 a, b) corresponding to the crust formed between $M-0$ and $M-4$ time, is about 110 to 120 m.y. old rather than 135 m.y. As previously discussed, the basement age at Site 384, together with other data, casts doubt on the hypothesis that the $J$-anomaly ridge is a sliver of continental crust (Gradstein et al., 1977; Grant, 1977). The Site 384 basement age also appears to rule out a suggestion made by some authors (e.g., Barrett and Keen, 1976) that the $J$-anomaly ridge lies in the middle of the Keathley se- quence. If it did, we would have expected ages some 10 to 20 m.y. older.

Site 386 is on the southern edge of a minor fracture zone (Figure 11). The basement is lower Albian, according to the nannofossils immediately above basalt. The detailed aeromagnetic data southwest of Bermuda (Figure 5) give us confidence in placing the site 110 km east-southest of anomaly $M-0$. Since the date of anomaly $M-0$ was predicted by Larson and Hilde (1975) to be about late Aptian, and this was also the date determined for DSDP Sites 417 and 418, the Site 386 basement age does not call for any major revision in this part of the reversal time scale. The difference in basement ages between Sites 417-418 and Site 386 is not more than around 5 m.y. (Aptian versus Albian). An age difference of this magnitude would suffice to account for the $110 \mathrm{~km}$ of ocean crust between $M-0$ and Site 386 at reasonable mid-Cretaceous spreading rates $(\sim 2 \mathrm{~cm} /$ year; Figure 11$)$.

Elsewhere in this volume, Keating and Helsley describe the magnetostratigraphy of Cretaceous sediments recovered at Site 386. Similarly, Opdyke and Larson report the magnetostratigraphy in the Maestrichtian to Paleocene sediments cored at Site 384 . The reversed periods in the Maestrichtian come as no surprise, since most authors now place anomalies 30 to 33 in the Upper Cretaceous. The most recent compilation (La Brecque et al., 1977) places one reversed period in the lower Campanian and five in the Maestrichtian. Although the data are of dubious quality, the Cretaceous/Tertiary boundary at Site 384 probably also lies in the $\sim 0.3$-m.y.-long reversed period between anomalies 29 and 30 (see Obdyke and Larson, this volume). This result is consistent with the magnetostratigraphy of the Italian "Gubbio" section (Alvarez et al., 1977).

The mid-Cretaceous between the Keathley (or $M$ ) sequence (Vogt et al., 1971a; Larson and Pitman, 1972) and anomalies 32 through 34 has long been thought to be characterized by predominantly or entirely normal polarity. From the study of magnetic anomalies in the Pacific, however, an additional reversed period has been found post-dating the original Keathley $(M)$ sequence. The negative anomaly $(M-0$; Larson and Hilde, 1975), representing the last long reversed period of the $M$-sequence, can also be seen in Atlantic areas of good data coverage (e.g., Figure 5). Since Site 386 lies some $110 \mathrm{~km}$ east of $M-0$, one might expect sediments of entirely normal polarity above the basalt; but brief reversed intervals occur in Cores 52 (upper Albian-Cenomanian), 53 (upper Albian), and 59 (lower Albian) (Keating and Helsley, this volume). These findings corroborate previous suggestions (Keating and Helsley, 1978b) that post-Keathley reversed intervals may have occurred within Albian and Cenomanian time. In the literature compilation of van Hinte (1976 b), a 1-m.y.-long reversed "Gatan" interval (108.5 to 107.5 m.y.B.P.) corresponds to the Albian/ Aptian boundary, and a "mixed" zone of short reversed intervals in the upper Albian corresponds to about 101 to 102 m.y.B.P. on that author's time scale. 
It is tempting to correlate the reversed interval in Core 59 with the Gatan interval. The 1.5 to 2.0 meters of reversely magnetized sediment would correspond to about 0.08 to $0.1 \mathrm{~m}$.y. at the $\sim 2 \mathrm{~cm} / 1000$ years sediment accumulation rate derived for this formation (see section on Sediment Accumulation Rate, Site 386). The two brief reversed intervals in Cores 52 and 53 might well correspond to the mixed polarities in the upper Albian at Site 263 (van Hinte, 1976b). Their duration could not have been more than 0.05 m.y. if sediment accumulation rates were reasonably constant. Is there any point in looking for such brief intervals in magnetic anomaly profiles? In the Atlantic, with its relatively slow spreading $(2.4 \mathrm{~cm} /$ year; Figure 11$)$ and complex basement topography, the task is not promising. Perhaps evidence for such intervals can be found in magnetic profiles crossing the Cretaceous "quiet zone" (Figure 10). Moreover, the fast spreading rates of the Cretaceous Pacific have made it possible to detect several polarity intervals as short as $0.03 \mathrm{~m} . \mathrm{y}$. from inspection of magnetic anomalies (Larson and Hilde, 1975). There is thus good reason to hope that at least one of the Albian reversed intervals detected in Site 386 sediment by Keating and Helsley (this volume) can be found in anomaly form.

\section{Implications for Sea-Floor Spreading Rates}

The spreading history of the central Atlantic was highly speculative until Leg 11 of the Deep Sea Drilling Project. Although the earliest, pre-Oxfordian history can still only be guessed at by extrapolation, subsequent drilling has added considerable refinement. Since Leg 43 added three basement ages to this history, we have attempted to update the "age-distance curve" for the central North Atlantic (Figure 11).

In constructing this curve, we interpolated all dates to a flow line passing through Site 386 and paralleling the nearest calculated flow lines (spreading directions) of Pitman and Talwani (1972). No major errors are introduced if the actual flow lines do not exactly parallel those computed by those authors. For the major postLate Cretaceous magnetic anomalies, we have plotted the data according to the reversal chronalogies of Heirtzler et al. (1968), Sclater et al. (1972), and Tarling and Mitchell (1976). A La Brecque et al. (1977) curve is not plotted, but would lie inside the envelope. All older basement ages are plotted according to the van Hinte (1976a, b) stratigraphic time scale generally adopted in this volume. Pacific dates of $M$-series anomalies (e.g., Sites 303 and 304) are plotted at the corresponding Atlantic $M$-series positions determined from the magnetic profiles (Figures 1, 2, and 5). The solid line is perhaps the simplest interpretation of these data. It suggests that spreading took place at a relatively constant high rate (labeled " $2.38 \mathrm{~cm} /$ year") from about the time of the Bermuda discontinuity (Vogt et al., $1971 \mathrm{a}, \mathrm{b}$, Figure 5) to the end of the Cretaceous, when rates began to decline. A rate of $1.22 \mathrm{~cm} /$ year fits all Keathley sequence data reasonably well, and intercepts the suggested continental margin at about 190 m.y.B.P. Obviously, the indicated rates are long-term averages; short-period rate fluctuations, if any, cannot be resolved by the data. Even the average rates depend on the stratigraphic time scale and other considerations, and could be substantially in error.

Although the history of central Atlantic spreading is still sharply limited by the uncertain stratigraphic time scale, we can infer that Keathley spreading rates were about 1 to $2 \mathrm{~cm} /$ year at this latitude. In itself, Figure 11 provides no grounds for inferring variations within the sequence, as postulated by Larson and Hilde (1975). A constant rate of about $1.2 \mathrm{~cm} /$ year from 190 to 110 m.y.B.P. will not violate any DSDP ages or upset the idea that early terrestrial igneous activity immediately preceeds or accompanies the onset of ocean floor spreading.

Finally, we want to mention the mid-Cretaceous pulse of rapid spreading, deduced by Larson and Pitman (1972) largely from their calibration of the Keathley reversals. Hays and Pitman (1973) went on to calculate the extra volume of ocean water displaced by these fast-spreading ridges, and attempted to explain the great mid-Cretaceous transgressions as a consequence of rapid spreading. The postulated effect is directly related to the calibration of the Keathley sequence, and has been questioned by some authors (Baldwin et al., 1974; Berggren et al., 1975). If these reversals occurred over a long period, the Cretaceous interval of normal polarity took less time and the seafloor during this normal interval was generated at a faster rate. Larson and Pitman (1972) and Larson and Hilde (1975) assigned anomalies $M-1$ and $M-21$ to the period 112 to 148 m.y.B.P., a 36-m.y. span. When their calibration line is plotted on van Hinte's stratigraphic time scale, this period becomes 116 to 144 m.y.B.P., a 28-m.y. interval. Our recalibration, using Leg 43 data and the van Hinte time scale, gives an interval of 27 m.y. (114.5 to 141.5 m.y.B.P.; Figures 12 and 13). Van Hinte's (1976b) own calibration of the Keathley sequence has $M$-1 to $M$-21 formed during an even briefer interval (120 to 140.5 m.y.B.P., or 20.5 m.y.). Meanwhile, the age of anomaly 32 has been decreased from 75 m.y. (Larson and Pitman, 1972) to 70 m.y. (van Hinte, 1976b; La Brecque et al., 1977). We suggest that the interval between anomalies 30 and $M-1$ is somewhat longer (44 m.y.) than proposed by Larson and Pitman (1972); thus, the mid-Cretaceous spreading rates were probably not so high as first suggested. Nevertheless, the 100 per cent spreading-rate increase from Keathley to Cretaceous- normal time is still dramatic (Figure 11). As a result almost half the crust in the central North Atlantic is Cretaceous! We may speculate that the rate change occurred at the time the $J$-anomaly ridge was formed $(M-4$ to $M-0$ time; Tucholke and Vogt, this volume), although the age-distance data do not demand that the curve bend exactly there.

\section{Recalibrating the Keathley Sequence}

In recalibrating the Keathley $(M)$ reversal sequence (Figure 13; Table 1), we started with the reversal boundaries deduced by Larson and Hilde (1975) from 


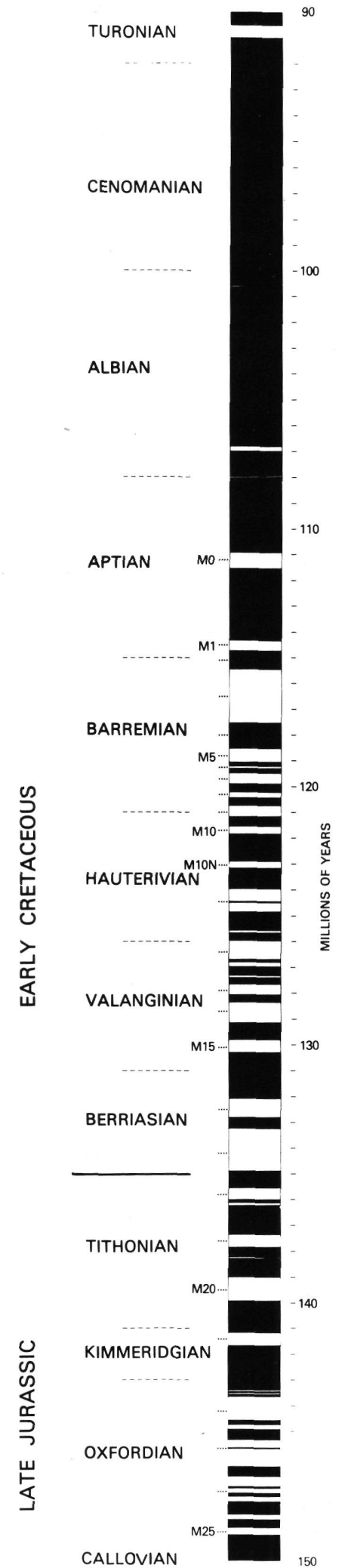

Figure 13. Revised calibration of Keathley sequence (Mseries) of geomagnetic refersals, based on Leg 43 drilling (Sites 384 and 387) and new stratigraphic time scale for Cretaceous and Jurassic (van Hinte 1967a, b). Normal periods are black. Position of reversals younger than M-O is approximate (Keating and Helsley, this volume and $1978 a, b)$. Note that differences between this calibration and the earlier one (Larson and Hilde, 1975) are not large.
TABLE 1

Revised Reversal Chronology

\begin{tabular}{|c|c|}
\hline $\begin{array}{c}\text { End of } \\
\text { Interval (m.y.B.P.) }\end{array}$ & $\begin{array}{c}\text { Beginning of } \\
\text { Interval (m.y.B.P.) }\end{array}$ \\
\hline 90.00 & 90.50 \\
\hline 91.00 & 100.50 \\
\hline 100.55 & 100.60 \\
\hline 100.65 & 106.80 \\
\hline 107.00 & 110.92 \\
\hline 111.55 & 114.34 \\
\hline 114.74 & 115.44 \\
\hline 117.53 & 118.52 \\
\hline 119.05 & 119.19 \\
\hline 119.31 & 119.47 \\
\hline 119.87 & 120.20 \\
\hline 120.43 & 120.72 \\
\hline 121.18 & 121.54 \\
\hline 121.87 & 122.21 \\
\hline 122.26 & 122.58 \\
\hline 122.61 & 122.91 \\
\hline 123.17 & 123.97 \\
\hline 124.42 & 124.47 \\
\hline 124.84 & 125.55 \\
\hline 125.66 & 125.96 \\
\hline 126.69 & 126.78 \\
\hline 126.97 & 127.30 \\
\hline 127.41 & 127.65 \\
\hline 128.07 & 128.34 \\
\hline 129.15 & 129.79 \\
\hline 130.30 & 132.08 \\
\hline 132.81 & 133.25 \\
\hline 134.90 & 135.54 \\
\hline 136.00 & 136.13 \\
\hline 136.23 & 137.35 \\
\hline 137.85 & 138.21 \\
\hline 138.27 & 139.00 \\
\hline 139.93 & 141.15 \\
\hline 141.67 & 143.39 \\
\hline 143.45 & 143.50 \\
\hline 143.56 & 143.65 \\
\hline 144.57 & 144.72 \\
\hline 144.92 & 145.32 \\
\hline 145.63 & 145.67 \\
\hline 146.36 & 146.72 \\
\hline 147.13 & 147.17 \\
\hline 147.39 & 147.52 \\
\hline 147.82 & 148.21 \\
\hline 148.40 & 148.72 \\
\hline 149.00 & 150.00 \\
\hline
\end{tabular}

magnetic anomalies in the Pacific. (Atlantic data, although much more detailed in terms of track density [e.g., Figure 5], lack resolving power because of slow spreading rates.) We then graphed the age ranges of diagnostic fossils from the bottoms of various DSDP drill holes against their equivalent magnetic anomaly positions on the Hawaiian lineation pattern (Figure 12). This graph, a revision of Larson and Hilde's (1975) Figure 4, is based on the stratigraphic time scale of van Hinte (1976a, b). (Larson and Hilde had assigned constant time intervals to all the stages of the Early Cretaceous and Late Jurassic.) Clearly, the data of Figure 12 cannot be fit by a straight line without violating the basement age at Site 387. We therefore divided the Keathley reversals into two groups of blocks, $M-0$ to $M-15$ and $M-15$ to $M-25$. An age of 130 m.y. was assigned to $M-15,149$ m.y. to the older edge of the $M-25$ reversed period, and $111 \mathrm{~m}$.y. to the upper edge of the $M-0$ reversal. The other block boundaries 
were then interpolated; the resulting reversal sequence is shown in Figure 13 (see also Table 1). We added several short reversed blocks above $M$-0 (using the results of Keating and Helsley, this volume, and van Hinte, 1976a, b). The lengths and positions of these blocks are only rough estimates, and should not be taken literally; clearly, magnetic anomaly data are needed for their verification and positioning between $M-0$ and 34 .

Other than our use of the van Hinte $(1976 a, b)$ time scale, the main revision we made is based primarily on one DSDP site, 387. Although we have interpreted the oldest sediment-which is well dated-as indicative of basement age, it is possible that a sill was injected above preexisting older sediments, and that basement is in fact older than lower Valanginian.

If the basement age for $M-15 / 16$ was correctly determined at Site 387 (and this needs to be verified by further drilling), then the Hawaiian lineations were not formed at a constant spreading rate. This would imply that Keathley spreading rates in the Atlantic were more nearly constant than had been assumed.

\section{CONCLUSION}

We have reviewed and updated the very detailed body of data on ocean crust magnetism in the western North Atlantic (Figures 1 through 10). In the last 5 to 10 years this body of data has grown somewhat, but the principal revisions in our understanding of the North Atlantic have come from the Deep Sea Drilling Project. Future revisions are not likely to be as spectacular as those of the last half-decade. Nevertheless, the outstanding problems that remain-for example, the origin of Cretaceous "quiet zone" anomalies, the nature and age distribution of the Jurassic quiet zone crust, and the meaning of the "rough-smooth transition" (Figure 4)-will not be solved without further drilling. As regards the Keathley reversal sequence, we can expect some further refinement, but probably no major revisions will emerge either from further analysis of Pacific sea-surface magnetic data or from additional drilling. The erection of reversal chronologies and the calculation of spreading rates depend heavily on the stratigraphic time scale, and it is likely that refinement of this time scale will further our understanding of spreading and reversals no less than the collection of more data from the oceanic basins.

\section{ACKNOWLEDGMENTS}

This paper is dedicated to the late Henry Stockard, under whose able leadership the Magnetics Division of the U.S. Naval Oceanographic office collected and processed the kind of high-quality data summarized in this paper. Ron Lorentzen kindly made available the Project MAGNET data in Figures 5 through 9. We also thank Robert Higgs for continuous encouragement of magnetic analysis; D. R. Bracey for much of the work compiling the contour chart in Figure 3; L.
Hemler for assistance with Figure 2; and A. Lowrie, W. Jahn, and the late Leonard Dennis for their help in executing the 1969 aeromagnetic survey north of Bermuda (Figure 6).

Special thanks are due Olav Eldholm and Gisle Gronlie for review. This paper was written while the senior author was on sabbatical at the Department of Geology, University of Oslo.

\section{REFERENCES}

Alvarez, W., Arthur, M. A., Fischer, A. G., Lowrie, W., Napoleone, G., Premoli Silve, I., and Roggenthen, W. M., 1977. Upper Cretaceous-Paleocene magnetic stratigraphy at Gubbio, Italy: V. Type section for the Late CretaceousPaleocene geomagnetic reversal time scale, Geol. Soc. Am. Bull., v. 88 , p. $383-389$.

Anderson, C. N., Vogt, P. R., and Bracey, D. R., 1969. Magnetic anomaly trends between Bermuda and the BahamaAntilles Arc (abstract), EOS, Trans. AGU, v. 50, p. 189.

Baldwin, B., Coney, P. J., and Dickinson, W. R., 1974. Dilemna of a Cretaceous time scale and rates of sea-floor spreading, Geology, v. 2, p. 267-270.

Barrett, D. L. and Keen, C. E., 1976. Mesozoic magnetic lineations, the magnetic quiet zone, and sea-floor spreading in the Northwest Atlantic, J. Geophys. Ref., v. 81, p. 48754884.

Berggren, W. A., McKenzie, D. P., Sclater, J. G., and van Hinte, J. E., 1975. World-wide correlation of Mesozoic magnetic anomalies and its implications, discussion, Geol. Soc. Am. Bull., v. 86, p. 267-269.

Blakely, R. J., 1976. An age-dependent, two-layer model for marine magentic anomalies. In The geophysics of the $\mathrm{Pa}$ cific Ocean basin and its margin, The Woollard Volume, Geophys. Mono. 19: Washington (Am. Geophys. Union), p. 227-234.

Bracey, D. R., 1968. Structural implications of magnetic anomalies north of the Bahamas-Antilles islands, Geophysics, v. 33, p. 950-961.

Bracey, D. R. and Avery, O. E., 1963. Marine magentic survey off the southern Bahamas, Project M-15, U.S. Naval Oceanographic Office Tech. Rept. TR-160.

Cande, S. C. and Kristoffersen, Y., 1977. Late Cretaceous magentic anomalies in the North Atlantic, Earth Planet. Sci. Lett., v. 35, p. 215-224.

Dallmeyer, R. D., 1975. The Palisades Sill: A Jurassic Intrusion?, Geology, v. 3, p. 243-245.

Dietz, R. S., Holden, J. C., and Sproll, W. P., 1970. Geotectonic evolution and subsidence of the Bahama Platform, Geol. Soc. Am. Bull., v. 81, p. 1915-1928.

Drake, C. L., Ewing, J. I., and Stockard, H., 1968. The continental margin off the eastern United States, Canadian J. Earth Sci., v. 5, p. 993-1010.

Einwich, A. M., 1972. A magnetic zone west of the Smooth Zone, east coast of North America, EOS, Trans. AGU, v. 53 , p. 365.

Einwich, A. M. and Vogt, P. R., 1971. Continued studies of the magnetic smooth zone in the western North Atlantic, Am. Geophys. Union Trans., v. 52, p. 195.

Emery, K. O., Uchupi, E., Phillips, J. D., Bowin, C. O., Bunce, E. T., and Knott, S. T., 1970. Continental rise off eastern North America, Am. Assoc. Petrol. Geol. Bull., v. 54, p. 44-108.

Gradstein, F. M., Grant, A. C., and Jansa, L. F., 1977. Grand Banks and J-Anomaly Ridge: A geological comparison, Science, v. 197, p. 1074-1076. 
Grant, A. C., 1977. Multichannel seismic reflection profiles the continental crust beneath the Newfoundland Ridge, Nature, v. 270, p. 22-25.

Grow, J. A. and Markl, R. G., 1977. IPOD-USGS multichannel seismic reflection profile from Cape Hatteras to the Mid-Atlantic Ridge, Geology, v. 5, p. 625-630.

Hayes, D. E. and Pitman, W. C., III, 1970. Magnetic lineations in the North Pacific. In Hayes, J. D. (Ed.), Geological investigations of the North Pacific: Geol. Soc. Am. Mem. 126, p. 291-314.

Hayes, D. E. and Rabinowitz, P. D., 1975. Mesozoic magnetic lineations and the magnetic quiet zone off northwest Africa, Earth Planet. Sci. Lett., v. 28, p. 105-115.

Hays, J.D. and Pitman, W.C., III, 1973. Lithospheric plate motion, sea-level changes and climatic ecological consequences, Mature London, v. 246, p. 18-22.

Heezen, B. C., Tharp, M., and Ewing, M., 1959. The Floors of the Oceans, I, the North Atlantic, Geol. Soc. Am., Special Paper 65, p. 58.

Heirtzler, J. R. and Hayes, D. E., 1967. Magnetic boundaries in the North Atlantic Ocean, Science, v. 157, p. 185-187.

Heirtzler, J. R., Dickson, G. O., Herron, E. M., Pitman, W. C., and Le Pichon, X., 1968. Marine magnetic anomalies, geomagnetic field reversals, and motions of the ocean floor and continents, J. Geophys., Ref., v. 73, p. 2119 2136.

Helsley, C. E. and Steiner, M. B., 1969. Evidence for long intervals of normal polarity during the Cretaceous period, Earth Planet. Sci. Lett., v. 5, p. 325.

Hilde, T. W. C., Isezaki, N., and Wageman, J. M., 1976. Mesozoic seafloor spreading in the North Pacific. In The geophysics of the Pacific Ocean basin and its margin, the Woollard Volume: Washington (Am. Geophys. Union), p. 205-226.

Isezaki, N. 1973. Geomagnetic anomalies and tectonics around the Japanese Islands, Oceanogr. Mag., 24, 107158.

Jones, E. J. W. and Mgbatogu, C. C. S., 1977. Jurassic seafloor spreading in the eastern Equatorial Atlantic, Nature, v. 267 , p. $688-690$.

Keating, B. and Helsley, C. E., 1978. Magnetostratigraphy of Cretaceous age sediments from Sites 361, 363, and 364. In Bolli, H. M., Ryan, W. B. F., et al., Initial Reports of the Deep Sea Drilling Project, v. 40: Washington (U. S.) Government Printing Office), p. 459-468.

Keen, C. E. and Keen, M. J., 1974. The continental margins of eastern Canada and Baffin Bay. In Burk, C. A. and Drake, C. L. (Eds.), The Geology of Continental Margins: New York (Springer-Verlag), p. 361-407.

Klitgord, K. D. and Behrendt, J. C., 1976. Fracture zones and the quiet zone off the northeastern U.S. continental margin (abstract), EOS, Am. Geophys. Union, v. 57, p. 365.

La Brecque, J. L., Kent, D. V., and Cande, S. C., 1977. Revised magnetic polarity time scale for Late Cretaceous and Cenozoic time, Geology, v. 5, p. 330-335.

Larson, R. L. and Chase, C. G., 1972. Late Mesozoic evolution of the western Pacific Ocean, Geol. Soc. Am. Bull., v. 83 , p. $3627-3644$.

Larson, R. L. and Hilde, T. W. C., 1975. A revised time scale of magnetic reversals for the Early Cretaceous and Late Jurassic, J. Geophys. Res., v. 80, p. 2585-2594.

Larson, R. L. and Pitman, W. C., III, 1972. World-wide correlation of Mesozoic magnetic anomalies, and its implications, Geol. Soc. Am. Bull., v. 83, p. 3645-3662.

Laughton, A. S. and Whitmarsh, R. B., 1974. The Azores-Gibraltar plate boundary. In Kristjansson, L. (Ed.), Geody- namics of Iceland and the North Atlantic area: DordrechtHolland, (D. Reidel Publishing Company), p. 63-81.

Luyendyk, B. P. and Bunce, E. T., 1973. Geological study of the northwest African margin off Morocco, Deep-Sea Res., v. 20 , p. $537-549$.

Martin, R. G. and Case, J. E., 1975. Geophysical studies in the Gulf of Mexico. In Nairn, A. E. M. and Stehli, F. G., (Eds.), The ocean basins and margins: New York (Plenum Press), p. 65-106.

Mayhew, M. A., 1974. Atlantic continental margin of North America. In Burk, C. A. and Drake, C. L. (Eds.), The geology of continental margins: New York (Springer-Verlag), p. 391-407.

McElhinney, M. W. and Burek, P. J., 1971. Mesocois Paleomagnetic stratigraphy, Nature, v. 232, p. 98-102.

Meyerhoff, A. A. and Hatten, C. W., 1974. Bahamas salient of North America. In Burk, C. A. and Drake, C. L. (Eds.), The geology of continental margins: New York (SpringerVerlag), p. 429-446.

Mason, R. G. and Raff, A. D., 1961. A magnetic survey off the west coast of North America, $32^{\circ} \mathrm{N}$ latitude to $42^{\circ} \mathrm{N}$ latitude, Geol. Soc. Am. Bull., v. 72, p. 1259-1270.

Newell, N. D., 1955. Bahamian platforms. In Poldervaart, A., (Ed.), The crust of the earth: Geol. Soc. Am. Special Paper 62, p. 303-315.

Pitman, W. and Talwani, M., 1972. Sea-floor spreading in the North Atlantic, Geol. Soc. Am. Bull., v. 83, p. 619-645.

Rabinowitz, P. D., 1974. The boundary between oceanic and contiental crust in the western North Atlantic. In Burk, C. A. and Drake, C. L. (Eds.), The Geology of Continental Margins, New York (Springer-Verlag), p. 67-84.

Schouten, H. and Klitgord, K. D., 1977. Map showing Mesozoic magnetic anomalies: western North Atlantic, $U . S$. Geol. Survey Misc. Field Studies, Map MF915.

Sclater, J. G., Jarrard, R. D., McGowan, B., and Gartner, S., 1972. Comparison of magnetic and biostratigraphic time scales since the Late Cretaceous, In von der Borch, C., Sclater, J. G., et al., Initial Reports of the Deep Sea Drilling Project, v. 22: Washington (U.S. Government Printing Office), p. 381-386.

Scrutton, R. A., 1973. The age relationship of igneous activity and continental break-up, Geol. Mag., v. 3, p. 227-234.

Sheridan, R. E., 1974. Atlantic continental margin of North America. In Burk, C. A. and Drake, C. L., (Eds.), The geology of continental margins: New York (Springer-Verlag), p. 391-407.

Steiner, M. B., 1975. Mesozoic apparent polar wander and Atlantic plate tectonics, Nature, v. 254, p. 107-109.

Steiner, M. B. and Helsley, C. E., 1975. Late Jurassic magnetic polarity sequence, Earth Planet, Sci. Lett., p. 108112.

Tarling, D. H. and Mitchell, J. G., 1976. Revised Cenozoic polarity time scale, Geology, v. 4, p. 133-136.

Taylor, P. T. and Greenewalt, D., 1974. Nature of the roughsmooth magnetic transition in the western North Atlantic Ocean (abstract) EOS, Trans. AGU, v. 55, p. 676.

Taylor, P. T., Greenewalt, D., Watkins, N. D., and Ellwood, B. B., 1973. Magnetic property analysis of basalt beneath the quiet zone (abstract) EOS, Trans. $A G U$, v. 54, p. 255.

Taylor, P. T., Zietz, I., and Denis, L. S., 1968. Geologic implications of aeromagnetic data from the eastern continental margin of the United States, Geophysics, v. 33, p. 755780 .

Uyeda, S., Yasui, M., Horai, K., and Yabe, T., 1962. Report on geomagnetic survey during JEDS-4 Cruise, Oceanogr. Mag., v. 13, p. 167-183. 
van Hinte, J. E., 1976a. A Jurassic time scale, Am. Assoc. Petrol. Geol. Bull., v. 60 , p. $489-497$.

1976b. A Cretaceous time scale, Am. Assoc. Petrol. Geol. Bull., v. 60, p. 498-516.

Vine, F. J. and Matthews, D. H., 1963. Magnetic anomalies over oceanic ridges, Nature, v. 199, p. 947-949.

Vogt, P. R., 1973. Early events in the opening of the North Atlantic. In Tarling, D. H. and Runcorn, S. K. (Eds.), Implications of continental drift to the earth sciences: London (Academic Press), v. 2, p. 693-712.

1975. Changes in geomagnetic reversal frequency at times of tectonic change. Evidence for coupling between core and upper mantle processes, Earth Planet. Sci. Lett., v. 25, p. 313-321.

Vogt, P. R. and Johnson, G. L., 1971. Cretaceous sea-floor spreading in the western North Atlantic, Nature, v. 234, p. 22-25.

, 1973. Magnetic telechemistry of oceanic crust?, Nature, v. 245, p. 373-375.
Vogt, P. R., Lorentzen, G. R., and Dennis, L. S., 1970a. An aeromagnetic survey of the Keathley magnetic anomaly sequence between $34^{\circ} \mathrm{N}$ and $40^{\circ} \mathrm{N}$ in the western North Atlantic, Am. Geophys. U. Trans., v. 51, p. 274.

Vogt, P. R., Anderson, C. N., Bracey, D. R., and Schneider, E. D., 1970b. North Atlantic magnetic smooth zones, $J$. Geophys. Res., v. 75, p. 2955-2968.

Vogt, P. R., Anderson, C. N. and Bracey, D. R., 1971 a. Mesozoic magnetic anomalies, sea-floor spreading, and geomagnetic reversals in the southwestern North Atlantic, J. Geophys. Res., v. 76, p. 4796-4823.

Vogt, P. R., Johnson, G. L., Holcombe, T. L., Gilg, J. G., and Avery, O. E., 1971b. Episodes of sea-floor spreading recorded by the North Atlantic basement, Tectonophysics, v. 12, p. 211-234.

Walczak, J. E., 1963. A marine magnetic survey of the New England seamount chain, U. S. Naval Oceanographic Office Tech. Rept., v. 159, p. 37. 